U.S. Department of the Interior

U.S. Geological Survey

\title{
Preliminary Volcano-Hazard Assessment For Redoubt Volcano, Alaska
}

Open-File Report 97-857

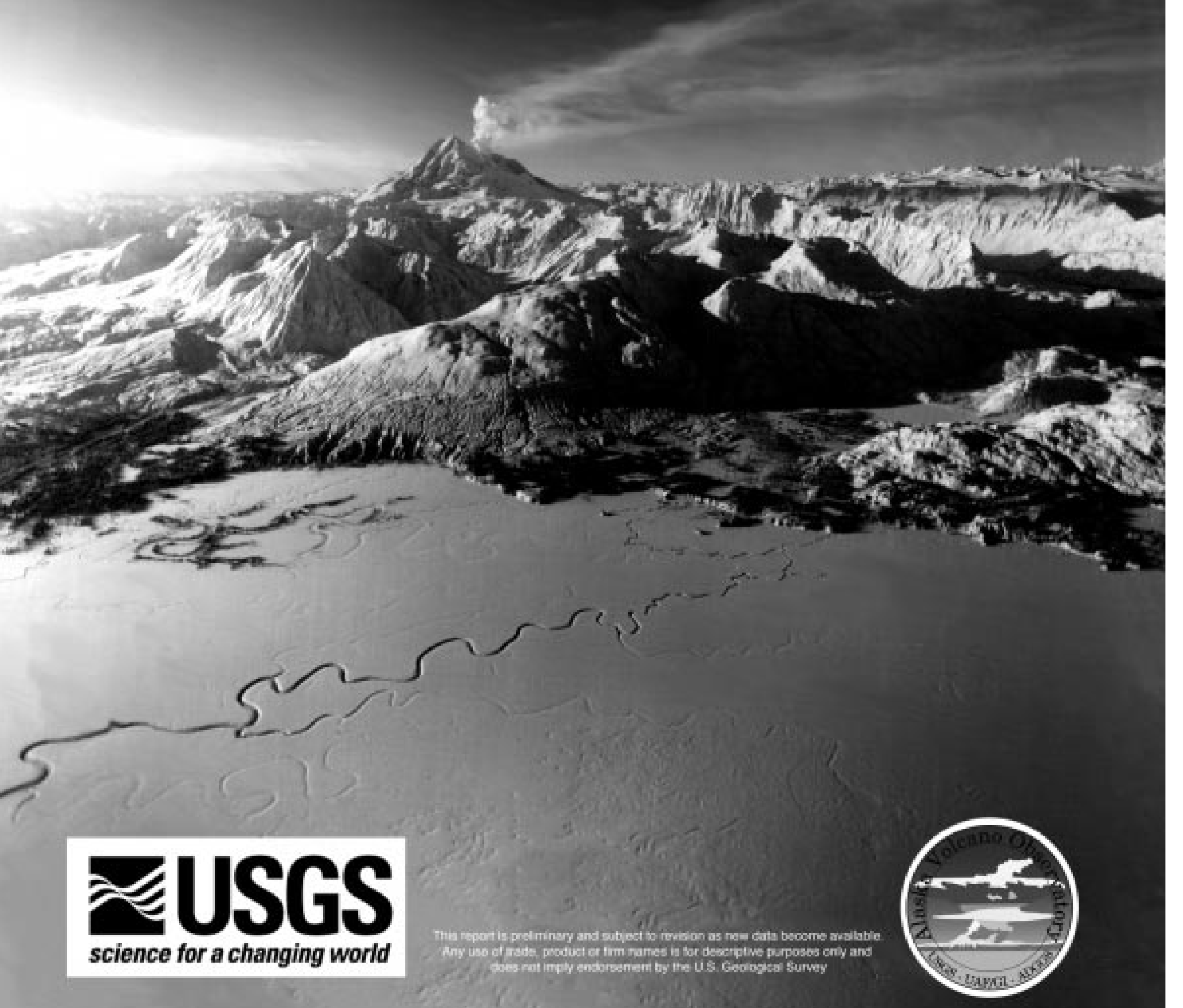


The Alaska Volcano Observatory (AVO) was established in 1988 to carry out volcano monitoring, eruption notification, and volcanic hazards assessments in Alaska. The cooperating agencies of AVO are the U.S. Geological Survey (USGS), the University of Alaska Fairbanks Geophysical Institute (UAFGI), and the Alaska Division of Geological and Geophysical Surveys (ADGGS). AVO also plays a key role in notification and tracking of eruptions on the Kamchatka Peninsula of Russia as part of a formal working relationship with the Kamchatkan Volcanic Eruptions Response Team (KVERT).

Cover photograph: Redoubt Volcano and low-level steam and ash plume, 1989. View is to the northwest. (Photograph by Jon J. Major, Cascades Volcano Observatory.) 
DEPARTMENT OF THE INTERIOR

U.S. GEOLOGICAL SURVEY

\title{
Preliminary Volcano-Hazard Assessment for Redoubt Volcano, Alaska
}

\author{
by \\ Christopher F. Waythomas, Joseph M. Dorava, Thomas P. Miller, \\ Christina A. Neal, and Robert G. McGimsey
}

Open-File Report 97-857

This report is preliminary and subject to revision as new data become available.

Any use of trade, product or firm names is for descriptive purposes only and does not imply endorsement by the U.S. Geological Survey

Alaska Volcano Observatory

Anchorage, Alaska

1998 


\section{U.S. DEPARTMENT OF THE INTERIOR \\ BRUCE BABBITT, Secretary}

U.S. GEOLOGICAL SURVEY

Mark Schaefer, Acting Director

For additional information:

U.S. Geological Survey Alaska Volcano Observatory 4200 University Drive

Anchorage, AK 99508

www.avo.alaska.edu
Copies of this report may be purchased from:

U.S. Geological Survey

Branch of Information Services

Box 25286

Denver, CO 80225-0286 


\section{CONTENTS}

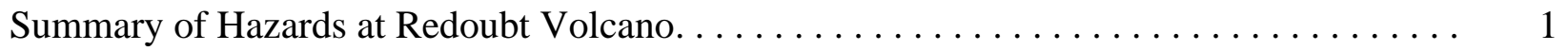

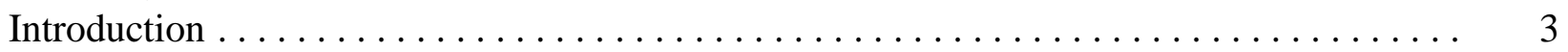

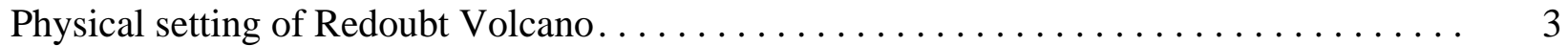

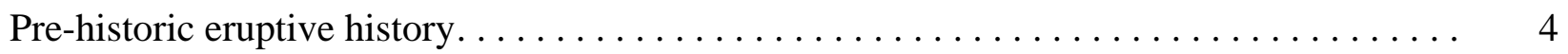

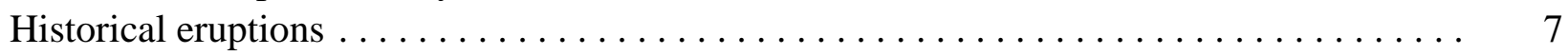

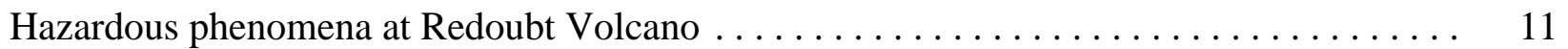

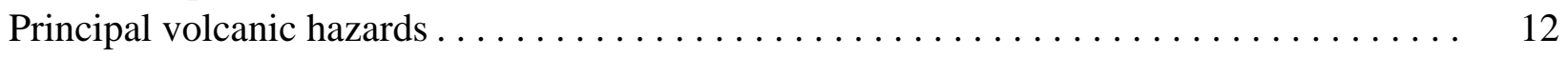

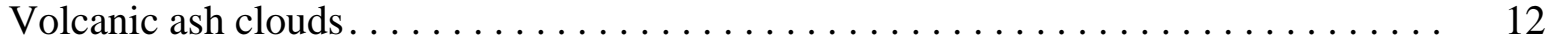

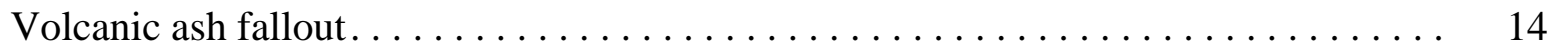

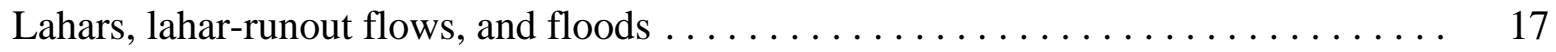

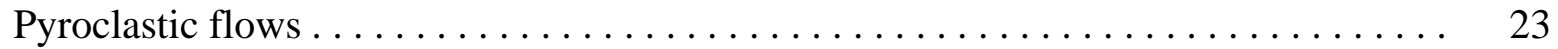

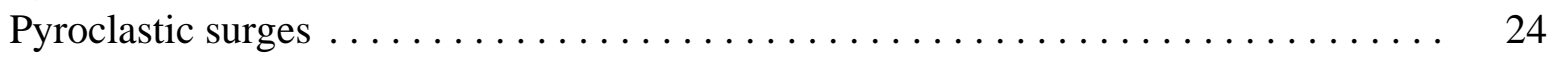

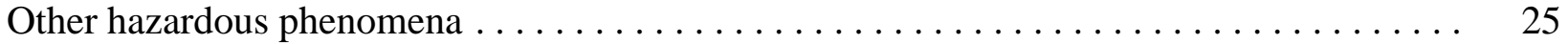

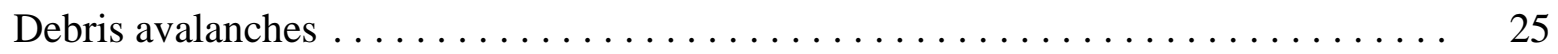

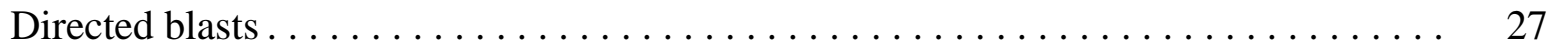

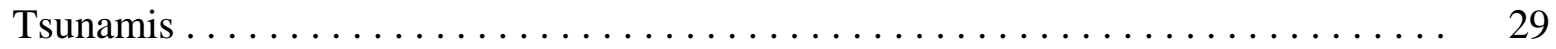

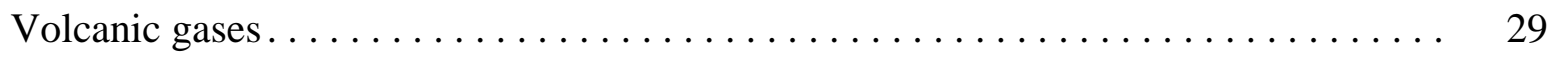

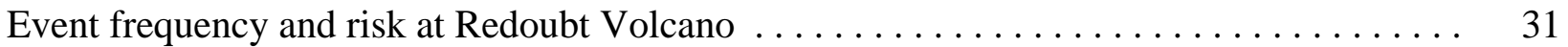

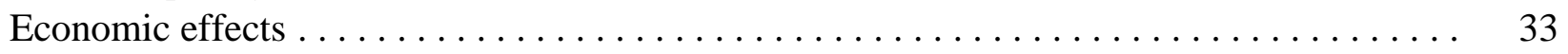

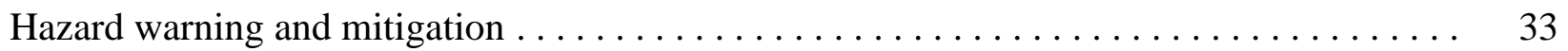

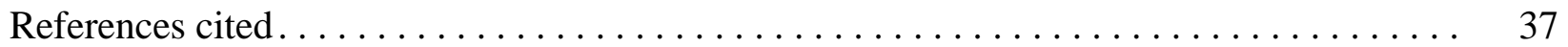

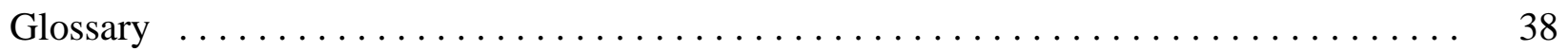

\section{ILLUSTRATIONS}

PLATE

1. Preliminary volcano-hazard assessment for Redoubt Volcano, Alaska [In pocket]

\section{FIGURE}

1. Map showing location of Redoubt Volcano with respect to other volcanoes in the

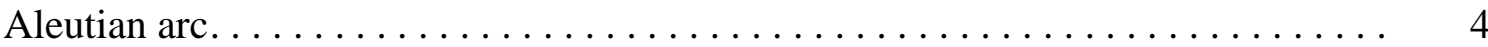

2. Map showing location of Redoubt Volcano with respect to other volcanoes

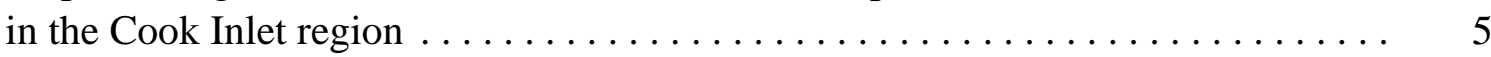

3. Diagram of chronology of known eruption-related events at Redoubt Volcano as determined from study of deposits in the immediate vicinity of the volcano . . . . 6

4. Sketch of known activity of Redoubt Volcano during the past 250 years . . . . . . 8

5. Photograph of ash cloud from Redoubt Volcano, December 16, $1989 \ldots \ldots \ldots \ldots$

6. Sketch maps of average wind direction and likely travel paths for volcanic ash clouds from Redoubt Volcano . . . . . . . . . . . . . . . . . . . . . . 
7. Map showing approximate extent of volcanic ash fallout from the 1989-90 eruption

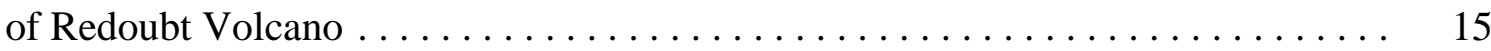

8. Sketch map of area likely to be affected by volcanic ash fallout from eruptions similar to the 1989-90 eruption of Redoubt Volcano . . . . . . . . . . . . . . . 16

9. Map showing areas likely to be affected by lahars, lahar-runout flows, and floods

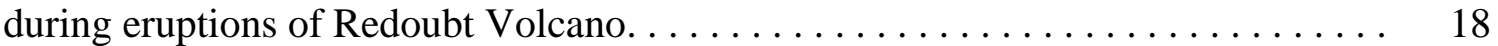

10-12. Photographs of:

10. Drift River Oil Terminal and lahars in Rust Slough, March 23, 1990 . . . . . . 19

11. Vertical aerial photograph of Drift Glacier piedmont lobe . . . . . . . . 20

12. Drift Glacier area. . . . . . . . . . . . . . . . . . . . . . . 21

13. Map showing Drift Glacier area and location of potential glacier-dammed lake. . . 22

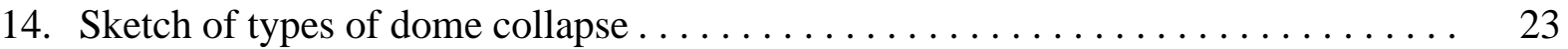

15. Graph of pyroclastic flow run-out length as a function of vent height for small

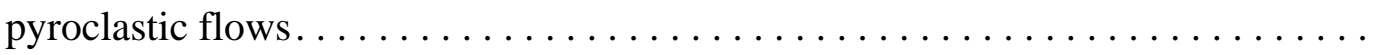

16. Map showing area most likely to be affected by pyroclastic flows and surges

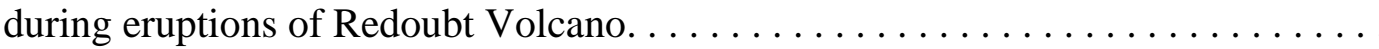

17. Photograph of approximate extent of pyroclastic surge deposits on Ptarmigan

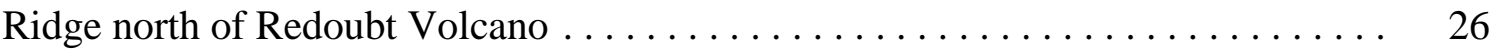

18. Map showing areas most likely to be affected by large-scale debris avalanches....

19. Graph of run-out distance as a function of volcano height for volcanic

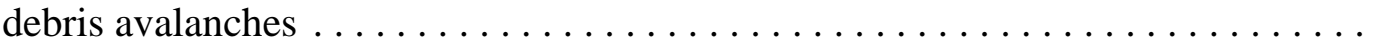

20-23. Maps showing:

20. Areas likely to be affected by directed blasts . . . . . . . . . . . .

21. Upper Cook Inlet and areas that could be affected by tsunamis caused by lahars and debris avalanches from Redoubt Volcano............... 30

22. Areas of the lower Drift River alluvial fan that were inundated by floods in May to August 1990, after the eruption . . . . . . . . . . . . . . . . . .

23. Location of seismic monitoring network on Redoubt Volcano . . . . . . . . . 34

24. Diagram of Alaska Volcano Observatory's level of concern color code . . . . . . . 35

25. Sketch of relative amount of risk from small versus large lahars moving down a typical stream channel . . . . . . . . . . . . . . . . . . .

\section{TABLES}

1. Summary of eruptive activity during the 1965-68 eruption of Redoubt Volcano . . 7

2. Summary of eruptive activity during the 1989-90 eruption of Redoubt Volcano . . . 9

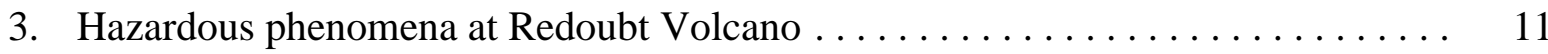

4. Ash-aircraft encounters during the 1989-90 eruption of Redoubt Volcano . . . . . . 14 
CONVERSION FACTORS

\begin{tabular}{rll}
\hline Multiply & By & \multicolumn{1}{c}{ To obtain } \\
\hline millimeter $(\mathrm{mm})$ & 0.03937 & inch \\
centimeter $(\mathrm{cm})$ & 0.3937 & inch \\
meter $(\mathrm{m})$ & 3.281 & foot \\
kilometer $(\mathrm{km})$ & 0.6214 & mile \\
cubic meter $\left(\mathrm{m}^{3}\right)$ & 35.31 & cubic foot \\
cubic kilometer $\left(\mathrm{km}^{3}\right)$ & 0.2399 & cubic mile \\
meter per second $(\mathrm{m} / \mathrm{s})$ & 3.28 & foot per second \\
cubic meter per second $\left(\mathrm{m}^{3} / \mathrm{s}\right)$ & 35.31 & cubic foot per second \\
& & \\
degree Celsius $\left({ }^{\circ} \mathrm{C}\right)$ & ${ }^{\circ} \mathrm{F}=1.8 \times{ }^{\circ} \mathrm{C}+32$ & degree Fahrenheit $\left({ }^{\circ} \mathrm{F}\right)$ \\
\hline
\end{tabular}




\title{
Preliminary Volcano-Hazard Assessment for Redoubt Volcano, Alaska
}

\author{
By Christopher F. Waythomas, Joseph M. Dorava, Thomas P. Miller, \\ Christina A. Neal, and Robert G. McGimsey
}

\section{SUMMARY OF HAZARDS AT REDOUBT VOLCANO}

Redoubt Volcano is a stratovolcano located within a few hundred kilometers of more than half of the population of Alaska. This volcano has erupted explosively at least six times since historical observations began in 1778. The most recent eruption occurred in 1989-90 and similar eruptions can be expected in the future. The early part of the 1989-90 eruption was characterized by explosive emission of substantial volumes of volcanic ash to altitudes greater than 12 kilometers above sea level and widespread flooding of the Drift River valley. Later, the eruption became less violent, as developing lava domes collapsed, forming short-lived pyroclastic flows associated with low-level ash emission. Clouds of volcanic ash had significant effects on air travel as they drifted across Alaska, over Canada, and over parts of the conterminous United States causing damage to jet aircraft. Economic hardships were encountered by the people of south-central Alaska as a result of ash fallout. Based on new information gained from studies of the 1989-90 eruption, an updated assessment of the principal volcanic hazards is now possible. Volcanic hazards from a future eruption of Redoubt Volcano require public awareness and planning so that risks to life and property are reduced as much as possible. The greatest hazards are described below in order of importance and are shown on plate 1:

\section{- Volcanic ash clouds}

During the 1989-90 eruption, a Boeing 747-400 jetliner flew into an ash cloud near Anchorage and lost power in all four engines. Fortunately, the engines were restarted and the plane landed safely, although major damage was incurred. Volcanic ash clouds drifted as far south as Texas causing damage to aircraft. Many aircraft must pass over Redoubt Volcano when arriving and departing Anchorage International Airport.

- Volcanic ash fallout

Fallout of volcanic ash resulted in numerous school and business closures and the Anchorage International Airport was closed. Many people experienced respiratory problems from inhaling fine ash particles.

\section{- Lahars and floods}

Hot volcanic debris interacts with snow and ice to form fast-moving slurries of water, mud, rocks, and sand. These flows, called lahars, completely inundated the Drift River valley downstream from

\section{THE ALASKA VOLCANO HAZARD ASSESSMENT SERIES}

This report is part of a series of volcano hazard assessments being prepared by the Alaska Volcano Observatory. The reports are intended to describe the nature of volcanic hazards at Alaska volcanoes and show the extent of hazardous areas with maps, photographs, and other appropriate illustrations. The reports are preliminary and subject to revision as new data become available. 
Redoubt Volcano several times during the 1989-90 and 1965-68 eruptions. Such flows pose a hazard to the Drift River Oil Terminal, located near the mouth of the Drift River. To protect the oil terminal, an extensive network of dikes and levees was constructed. The dike and levee system probably prevented an oil spill and since the 1989-90 eruption, an enhanced network of earthen dikes was built. Lahars and floods from future eruptions are not likely to harm this facility; however, during an extreme volcanic eruption, flows larger and more destructive than those of 1989-90 may occur along any of the drainages emanating from Redoubt Volcano.

\section{- Pyroclastic flows and surges}

Hot material expelled from the volcano may rapidly travel down the volcano flanks as hot flows of volcanic debris called pyroclastic flows and surges. Pyroclastic flows and surges were common during the 1989-90 eruptions and are a serious hazard in areas within about 15 kilometers of the volcano.

Other hazardous phenomena that may occur but are less likely during typical eruptions of Redoubt Volcano include:

\section{- Debris avalanches}

A debris avalanche is a rapidly moving mass of solid or incoherent rock that forms by a large-scale slope failure of the volcano flank. At least one prehistoric debris avalanche deposit has been identified at Redoubt Volcano. Debris avalanches may move at velocities ranging from tens to hundreds of meters per second, are quite voluminous (greater than 10 cubic kilometers), and may travel many tens of kilometers from their source. A debris avalanche at Redoubt Volcano would obliterate everything in its path and would introduce a large volume of sediment into its drainage basin.

\section{- Directed blasts}

A directed blast is a lateral explosion of the volcano caused by rapid release of internal pressure often caused by a slope failure or landslide. Geologic evidence for directed blasts has not been found at Redoubt Volcano, but other volcanoes similar to Redoubt, are known to have produced directed blasts.

\section{- Volcanic tsunamis}

Large debris avalanches that rapidly descend the volcano flanks and enter the sea may initiate volcanic tsunamis. Although a debris avalanche from Redoubt Volcano reached Cook Inlet 10,000 to 13,000 years ago, there is no evidence that it initiated a tsunami. The distance from Redoubt Volcano to the coast is about 35 kilometers and only the very largest known debris avalanches would be able to reach Cook Inlet over this distance. The probability of a debris avalanche reaching Cook Inlet is low, and thus, the probability of a tsunami associated with Redoubt Volcano is low.

\section{- Volcanic gases}

Although some volcanoes emit gases in concentrations that are harmful to humans, frequent windy conditions at Redoubt Volcano preclude the buildup of volcanic gases. Thus, the hazard from volcanic gases is minimal, unless one is actually on or in the active vent.

\section{SUGGESTIONS FOR READING THIS REPORT}

Readers who want a brief overview of the hazards at Redoubt Volcano are encouraged to read the summary and consult plate 1 and the illustrations Individual sections of this report provide a slightly more comprehensive overview of the various hazards at Redoubt Volcano. A glossary of geologic terms is included and additional information about Redoubt Volcano can be obtained by consulting the references cited in the text. 


\section{INTRODUCTION}

The 1989-90 eruptions of Redoubt Volcano caused economic losses estimated at more than $\$ 160$ million making it one of the most costly volcanic eruptions in U.S. history (Miller and Chouet, 1994). Most significant were the engine failures of a Boeing 747-400 passenger jet that flew into an ash cloud 220 kilometers north of Anchorage. Ash fallout in the region caused health concerns for residents; schools, businesses, and airports were closed; and people were advised to remain indoors. Volcanic mudflows called lahars, moved swiftly down the Drift River and threatened the Drift River Oil Terminal, a large oil storage and transfer facility near the mouth of Drift River. Fortunately, no oil was spilled, but the facility was partially flooded, and large volumes of sediment were deposited in the vicinity of the oil terminal causing unexpected shifts in the position of the channel. Most of the Drift River valley downstream from the volcano was inundated with water and sediment.

Since the eruption, scientists have learned much about the processes and hazards associated with eruptions of Redoubt Volcano (Miller and Chouet, 1994). This report describes and summarizes the hazards associated with eruptions of Redoubt Volcano based on this new knowledge, and updates previous reports about volcano hazards at Redoubt Volcano (Brantley, 1990; Till and others, 1993).

This report summarizes the principal volcanic hazards associated with eruptions of Redoubt Volcano. Hazardous volcanic phenomena that occur on the volcano as well as distal effects of eruptions are described. The present status of monitoring efforts to detect volcanic unrest and the procedure for eruption notification and dissemination of information also are presented. A series of maps and figures that indicate hazard zone boundaries are included. A glossary of geologic terms is at the end of the report.
PHYSICAL SETTING OF REDOUBT VOLCANO

Redoubt Volcano is part of a chain of volcanoes extending from south-central Alaska to the far western end of the Aleutian Islands (fig. 1). This belt of volcanoes is called the "Aleutian arc", and it is home to more than 40 active volcanoes. This area averages 3 to 5 eruptions every year making it one of the most active volcanic regions in the world (Simkin and Siebert, 1994). Redoubt Volcano is one of three volcanoes in the Cook Inlet region that has erupted several times in the last 150 to 200 years. The volcano is located about 180 kilometers southwest of Anchorage and more than half of the population of Alaska resides within 200 kilometers (fig. 2). The summit of the volcano is 3108 meters above sea level and much of the volcano is mantled by glacier ice and snow. Redoubt Volcano is in Lake Clark National Park and Preserve, and the area immediately surrounding it is unpopulated and undeveloped. In summer and fall, a small number of people visit the area for recreational purposes. Redoubt Volcano is beneath the flight path of commercial and private aircraft approaching or departing Anchorage and many aircraft pass over the volcano every day.

The Drift River Oil Terminal (fig. 2) is about 35 kilometers east of Redoubt Volcano and is situated along the south side of Drift River, about 5 kilometers inland from its mouth. The Drift River Oil Terminal includes seven oil storage tanks (maximum capacity 1.9 million barrels), an offshore oil-tanker pumping station, and a 0.5 -meter-diameter pipeline that extends from the offshore pumping station to the storage tanks. An additional pipeline brings oil to the terminal from production wells and other facilities to the north.

During the 1989-90 eruptions, personnel from the Drift River Oil Terminal were evacuated three times as lahars surrounded the terminal and threatened, but did not damage, the 


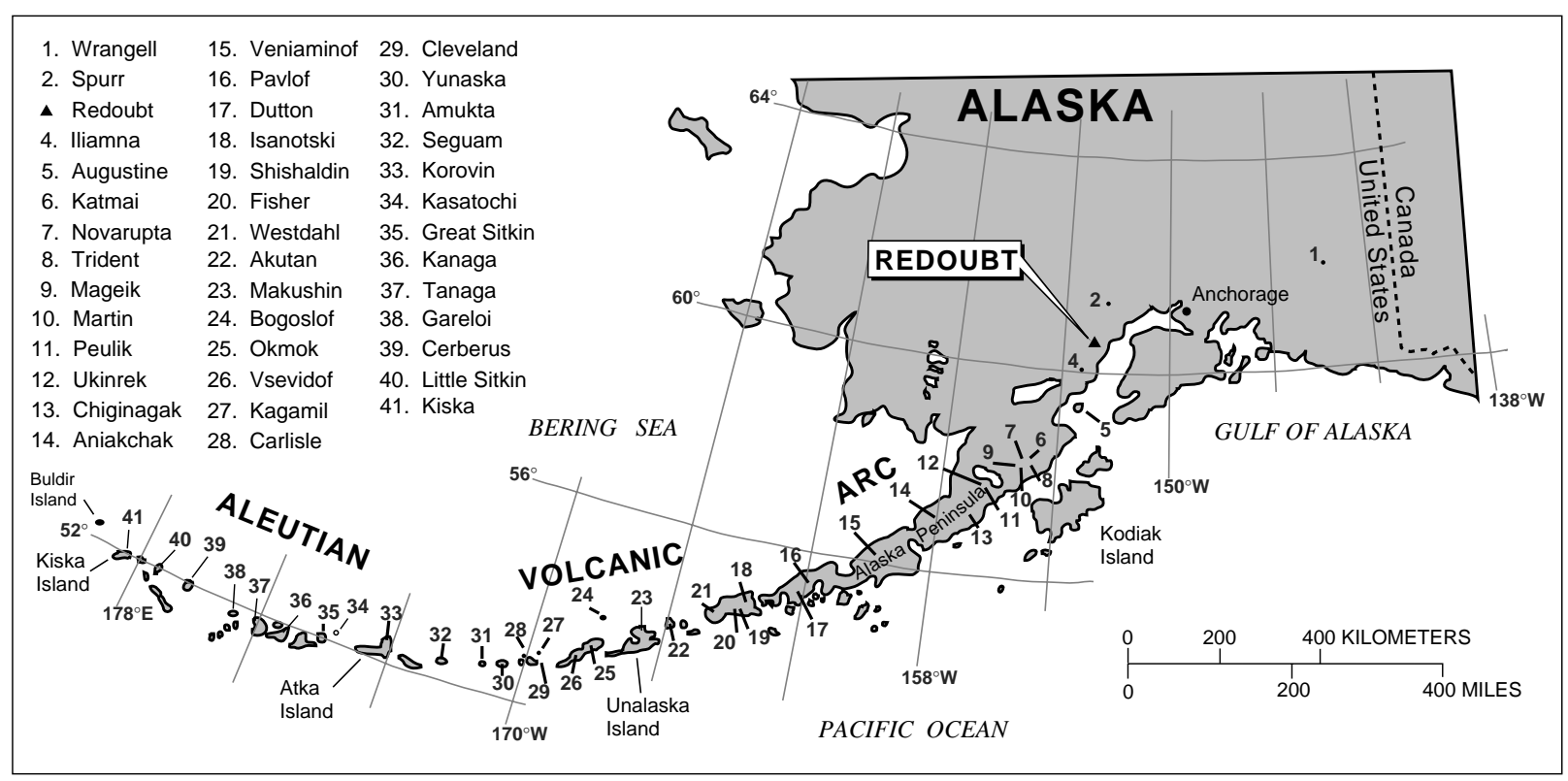

Figure 1. Location of Redoubt Volcano with respect to other volcanoes in the Aleutian arc. All of these volcanoes except Wrangell, Iliamna, and Dutton have erupted in the last 200 years.

oil storage tanks. The average daily amount of oil stored at the Drift River Oil Terminal is about 350,000 barrels (about 1.3 times the amount of oil spilled by the Exxon Valdez) and approximately 1 million barrels of oil were stored in the tanks when the 1989-90 eruption began. No oil was spilled during the 1989-90 eruptions.

\section{PRE-HISTORIC ERPUPTIVE HISTORY}

Redoubt Volcano is a cone-shaped stratovolcano that began forming about 880,000 years before present (Till and others, 1994). The frequency of Holocene ash-producing eruptions has been determined largely from studies of fine-grained volcanic ash (tephra) preserved in lakes and bogs in areas downwind from the volcano. Geochemical analysis and dating of buried tephra layers throughout the Cook Inlet region indicate that a minimum of 30 separate eruptions have occurred at Redoubt Volcano during the last 10,000 years (Riehle, 1985; Begét and others, 1992; Begét and Nye, 1994). However, not all eruptions produce enough tephra to be recognized in lake cores and the number of tephra layers preserved in areas around the volcano gives only a minimum estimate of the number of eruptions.

Recent work on the geology of the volcano itself provides new information about the earliest eruptive history. Till and others (1994) identified four major stages in the evolution of the volcano:

(1) An early explosive stage characterized by lahar and pyroclastic-flow activity and the extrusion of a lava dome, about 880,000 years before present (B.P.).

(2) An early cone-building stage characterized by thin lava flows, pyroclastic flows, and lahars that took place between 340,000 and 184,000 years before present.

(3) A late cone-building stage characterized by thick lava flows and pyroclastic flows that occurred some time after 184,000 years before present and before the beginning of the post-glacial period, about 10,000 years ago. 


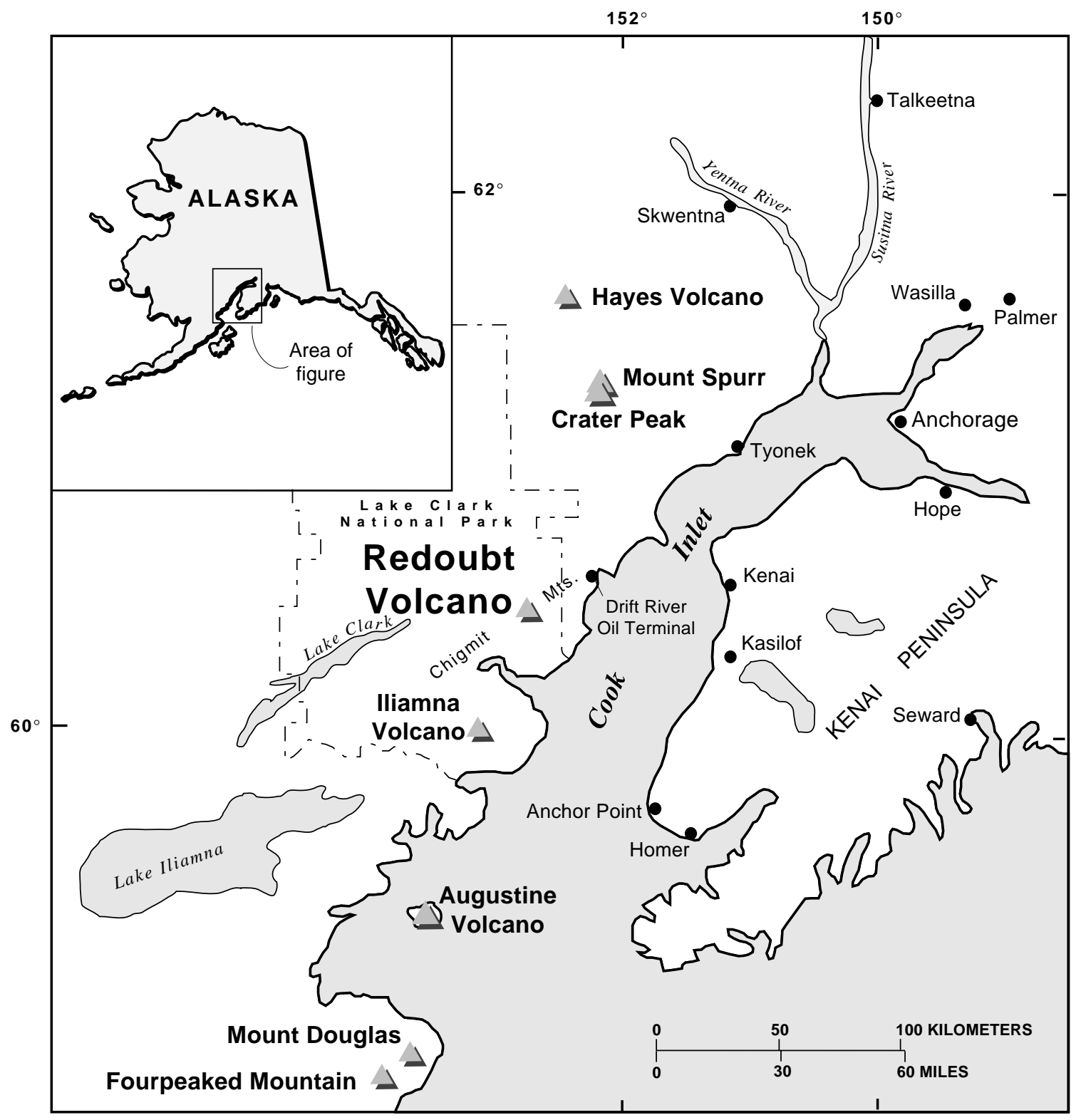

Figure 2. Location of Redoubt Volcano with respect to other volcanoes in the Cook Inlet region. Also shown are place names mentioned in text.

(4) A post-glacial (Holocene) stage characterized by deposition of fallout tephra, pyroclastic flows and lahars, from about 10,000 years before present until the historical period.

The eruptive history of Redoubt Volcano (fig. 3) provides much useful information for assessing future volcanic activity. The best indication of what may happen during future eruptions comes from studying and interpreting the distribution, character, and sequence of volcanic deposits from previous eruptions preserved around the volcano. Figure 3 illustrates the various volcanic processes and associated deposits that have been identified in the major drainages surrounding Redoubt Volcano. Age estimates are based on radiocarbon dating of organic remains associated with the most sig- 


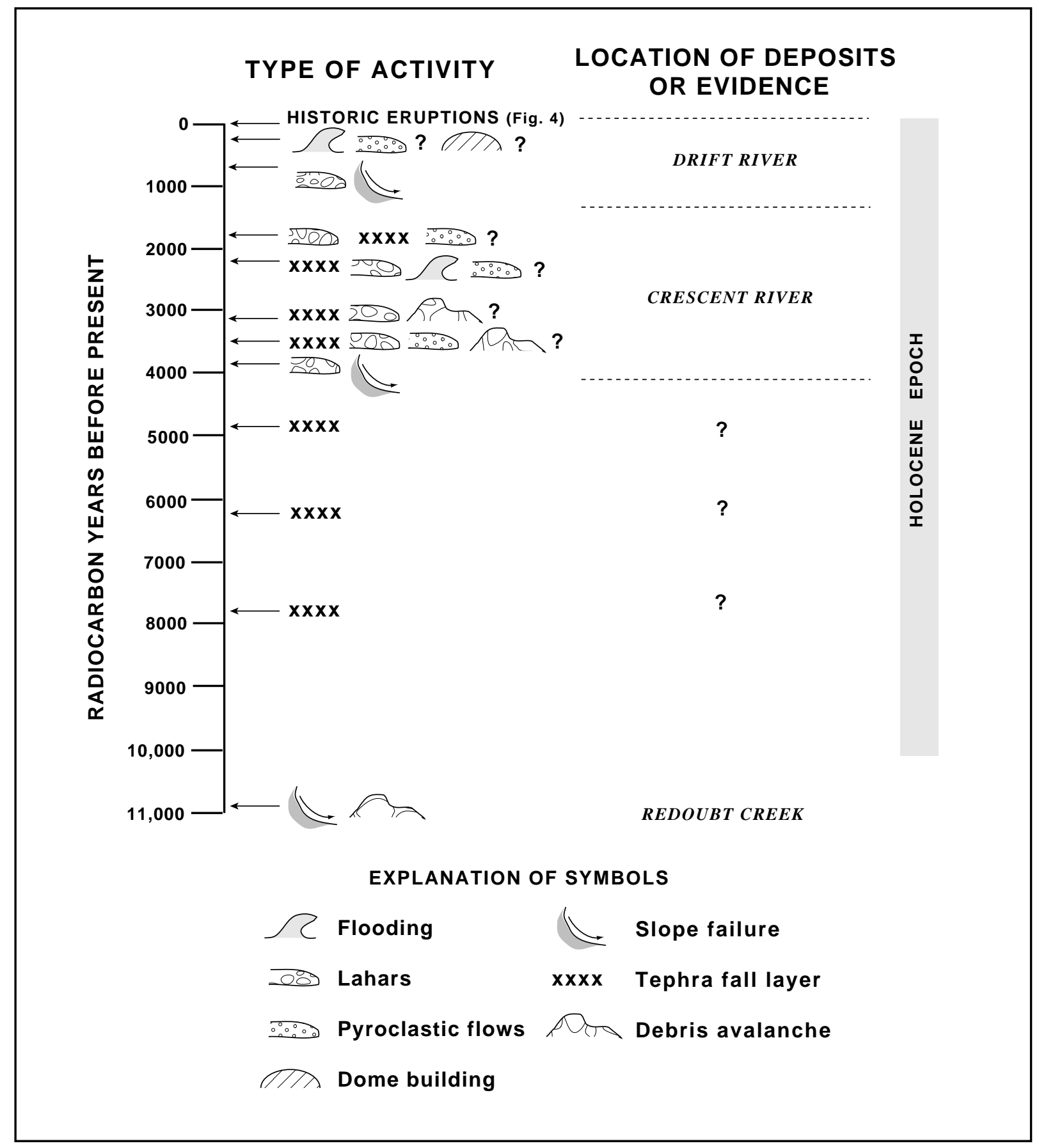

Figure 3. Chronology of known eruption-related events at Redoubt Volcano as determined from study of deposits in the immediate vicinity of the volcano (modified from Begét and Nye, 1994). The record of historic eruptions is given in Figure 4.

nificant deposits (Begét and Nye, 1994). About 30 Redoubt tephra layers (indicating 30 eruptions) have been identified in the lake sediments of Bear Lake, about 22 kilometers east of the volcano (Riehle, 1985). This more complete record indicates that Redoubt Volcano has erupted at least 30 times in about the last 10,000 years. 


\section{HISTORICAL ERUPTIONS}

The first report of historical activity at Redoubt Volcano was in 1778 when Captain James Cook observed the volcano steaming but not actually erupting. Since then, Redoubt has erupted at least five times (fig. 4). These eruptions produced ash (fig. 5) that fell on parts of the Kenai Peninsula and south-central Alaska. The 1989-90 eruption had a major impact on jet aircraft safety and the rapidly growing air-cargo industry in Anchorage. Eruptions in 1965-68 and 1989-90 also resulted in significant flooding of the Drift River downstream from the volcano. Volcanic mudflows (lahars) were generated in the Drift River valley when hot pyroclastic debris melted snow and large portions of the Drift Glacier. Water derived from the melted snow and ice mixed with sediment and transformed into lahars that travelled down the Drift River eventually reaching the Cook Inlet.
The eruptions that occurred between 1966 and 1968 were characterized by minor explosive eruptions, low-level ash emission, and possibly pyroclastic-flow activity in the upper Drift River valley (Sturm and others, 1986; Till and others, 1993). Although the eruptive period lasted from January 1965 to April 1968, the duration of individual eruptions was only minutes to hours to days, and long periods of quiescence were common (table 1). In contrast, the 1989-90 eruption was characterized by more frequent and continuous bursts of activity that included ash emission, commonly to 10,000 meters above sea level or more, pyroclastic flows, and lahars (table 2). The slightly longer duration and greater frequency of individual eruptions in 1989-90 along with increased development in the region, meant that the risk to life and property posed by this eruption was greater than during the 1965-68 eruption.

Table 1. Summary of eruptive activity during the 1965-68 eruption of Redoubt Volcano (modified from Till and others, 1993)

\begin{tabular}{|c|c|c|}
\hline DATE & TYPE OF ACTIVITY & DURATION \\
\hline Jan.- Feb. 1965 & - Steam emissions & $\begin{array}{l}\text { Intermittent (?) over } \\
\text { period }\end{array}$ \\
\hline Jan. 24, 1966 & $\begin{array}{l}\text { - Minor eruption, tephra emission } \\
\text { - Ash plume to about } 1,800 \text { meters altitude } \\
\text { - Pyroclastic flows (?) } \\
\text { - Lahars and floods that reached the lower Drift River }\end{array}$ & Hours to days \\
\hline $\begin{array}{l}\text { Jan. } 24 \text { - Feb. 20, } \\
1966\end{array}$ & $\begin{array}{l}\text { - At least six explosions recorded at College, Alaska, about } 550 \\
\text { kilometers from the volcano }\end{array}$ & $\begin{array}{l}\text { Seconds to minutes, } \\
\text { each explosion }\end{array}$ \\
\hline Feb.- March 1966 & - Lahars and floods along the Drift River & Days to weeks \\
\hline Jan. 1-15. 1967 & - Ash and steam emissions & Hours to days \\
\hline $\begin{array}{l}\text { Dec. } 7,1967- \\
\text { April } 28,1968\end{array}$ & $\begin{array}{l}\text { - At least five explosions recorded at College, Alaska, about } 550 \\
\text { kilometers from the volcano }\end{array}$ & $\begin{array}{l}\text { Seconds to minutes, } \\
\text { each explosion }\end{array}$ \\
\hline
\end{tabular}




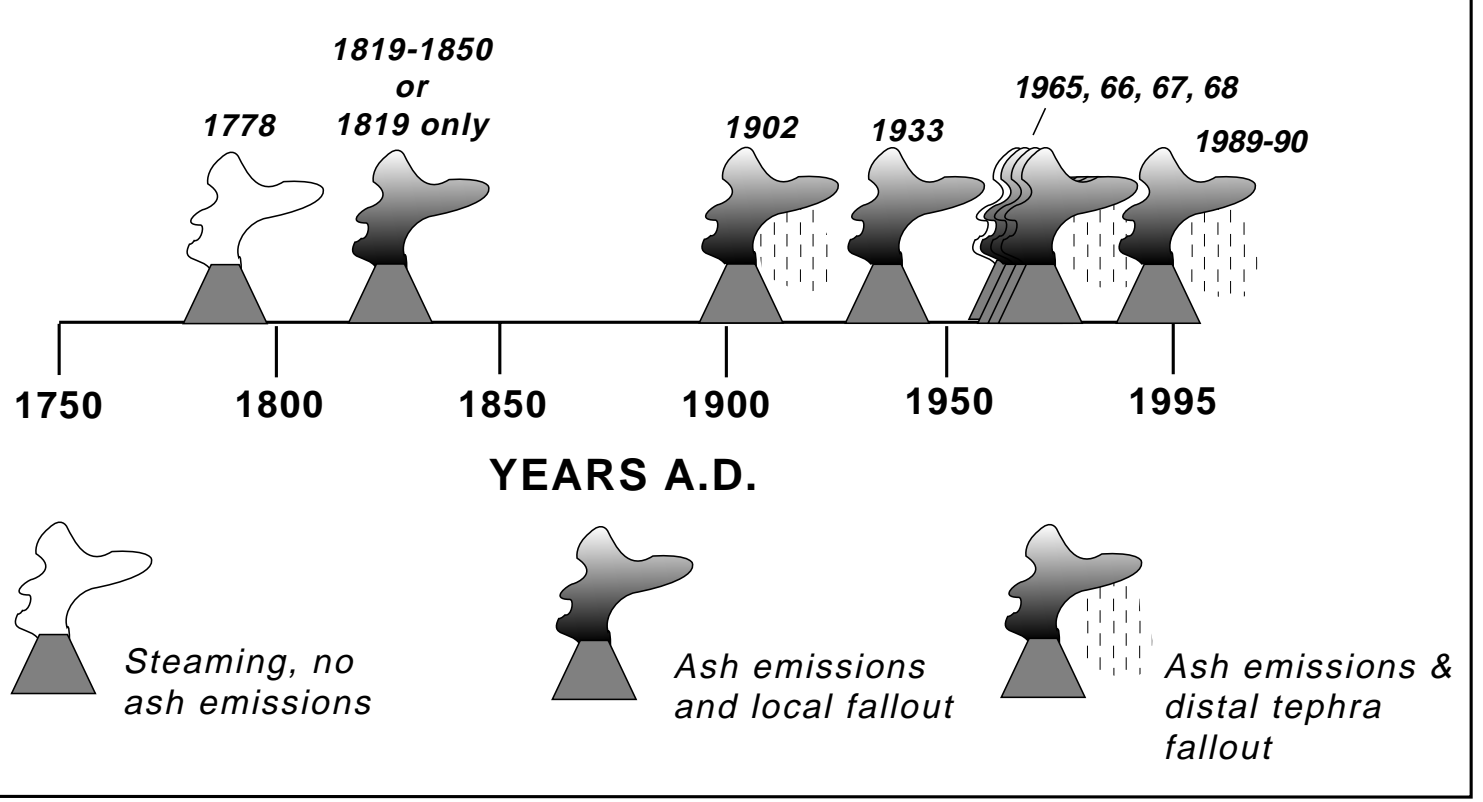

Figure 4. Known activity of Redoubt Volcano during the past 250 years. Accounts of volcanic activity in Alaska are incomplete and sketchy before about A.D. 1900. Cook's 1778 observation indicated that Redoubt was "emitting a white smoke but no fire" (Beaglehole, 1967, p. 370). This suggests a minor steam emission and not a full-scale eruption. The eruption of 1819 is based on reports of Redoubt "... smoking since 1819" (Petroff, 1884) and that "... in 1819 the Redoubt volcano of Cook's Inlet smoked..." (Dall, 1870, p. 499). These accounts indicate that Redoubt may have been in some state of eruption between 1778 and 1850; however, it appears that no major eruption took place during this interval.

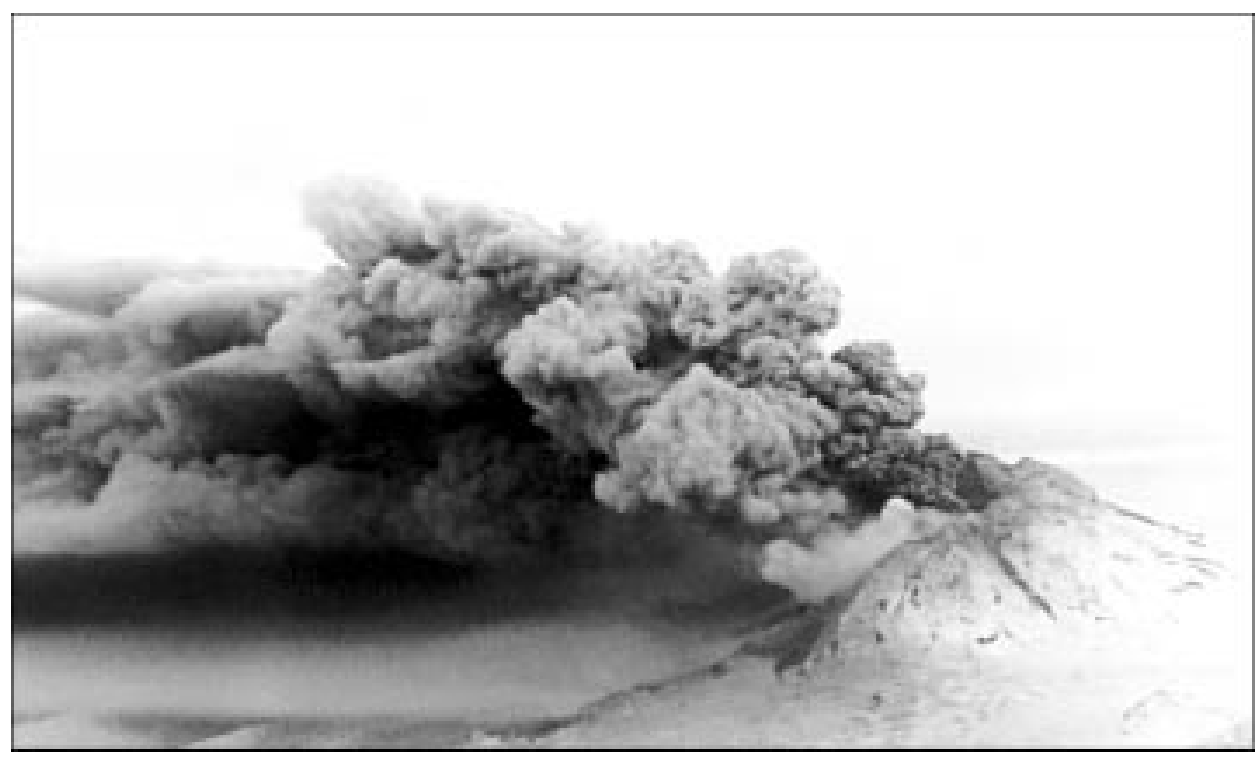

Figure 5. Ash cloud from Redoubt Volcano, December 16, 1989. View is to the southwest. Photograph by National Park Service. 
Table 2. Summary of eruptive activity during the 1989-90 eruption of Redoubt Volcano (modified from Brantley, 1990; Alaska Volcano Observatory Staff, 1990; Gardner and others, 1994; Miller and Chouet, 1994; and Scott and McGimsey, 1994)

\begin{tabular}{|c|c|c|}
\hline DATE & TYPE OF ACTIVITY & DURAT ION \\
\hline Nov. 20, 1989 & -Steaming from crater & Hours \\
\hline Dec. 8, 1989 & -Steam plume & $>5$ hours \\
\hline Dec. 13,1989 & $\begin{array}{l}\text {-Intense seismic swarm } \\
\text {-Vigorous steaming }\end{array}$ & Approx. 23 hours \\
\hline Dec. 14,1989 & $\begin{array}{l}\text {-Major explosive event, tephra emission } \\
\text {-Ash plume to >10,000 meters } \\
\text { - Lahars and floods in the Drift River valley }\end{array}$ & Minutes to hours \\
\hline Dec. 15,1989 & $\begin{array}{l}\text {-3 major explosive events, tephra emission } \\
\text {-Ash plume to }>12,000 \text { meters during the third event }\end{array}$ & Minutes to hours \\
\hline Dec. $15-19,1989$ & $\begin{array}{l}\text { - Nearly continuous steam and ash emission } \\
\text {-Minor explosive events } \\
\text {-Ash plume to }>9,000 \text { meters }\end{array}$ & Approx. 90 hours \\
\hline $\begin{array}{l}\text { Dec. 22, } 1989- \\
\text { Jan. 2, } 1990\end{array}$ & $\begin{array}{l}\text { - Formation of large lava dome } \\
\text { - Continuous convective steaming }\end{array}$ & 11 days \\
\hline Jan. 1 - 2, 1990 & -Increasing shallow seismic activity & 34 hours \\
\hline Jan. 2, 1990 & $\begin{array}{l}\text {-2 major explosive events } \\
\text { - Lava dome collapse } \\
\text {-Ash plume to } 12,000 \text { meters } \\
\text { - Lahars and flooding in Drift River valley } \\
\text { - Pyroclastic flows }\end{array}$ & Minutes to hours \\
\hline Jan. 3 - 8, 1990 & $\begin{array}{l}\text { - Continuous steaming } \\
\text {-Minor explosive events }\end{array}$ & Approx. 5 days \\
\hline Jan. 8, 1990 & $\begin{array}{l}\text { - Major explosive event } \\
\text { - Lava dome collapse } \\
\text { - Ash plume to }>12,000 \text { meters } \\
\text { - Pyroclastic flows } \\
\text { - Lahars and flooding in Drift River valley }\end{array}$ & 30 minutes \\
\hline Jan. 11, 1990 & $\begin{array}{l}\text { - Explosive steam emission, plume to } 10,000 \text { meters } \\
\text {-Near vent ash fall }\end{array}$ & Minutes \\
\hline Jan. 16, 1990 & $\begin{array}{l}\text {-Minor explosive event } \\
\text {-Ash plume to }>11,000 \text { meters } \\
\text { - Lahar in upper Drift River valley }\end{array}$ & Minutes \\
\hline Feb. 15, 1990 & $\begin{array}{l}\text { - Minor explosive event } \\
\text { - Lava dome collapse } \\
\text { - Ash plume to >10,000 meters } \\
\text { - Extensive pyroclastic flow and surge } \\
\text { - Lahars and flooding in Drift River valley }\end{array}$ & Minutes \\
\hline Feb. 21, 1990 & $\begin{array}{l}\text { - Minor explosive event } \\
\text { - Lava dome collapse } \\
\text { - Ash plume to 9,000 meters } \\
\text { - Lahar in upper Drift River valley }\end{array}$ & Minutes \\
\hline Feb. 24, 1990 & $\begin{array}{l}\text { - Minor explosive event } \\
\text { - Lava dome collapse } \\
\text { - Ash plume to 9,000 meters } \\
\text { - Lahars and flooding in Drift River valley }\end{array}$ & Minutes \\
\hline
\end{tabular}


Table 2.-Continued

\begin{tabular}{|c|c|c|}
\hline DATE & TYPE OF ACTIVITY & DURATION \\
\hline Feb. 28, 1990 & $\begin{array}{l}\text {-Minor explosive event } \\
\text { - Lava dome collapse } \\
\text {-Ash plume to >8,000 meters } \\
\text { - Lahars and flooding in Drift River valley }\end{array}$ & Minutes \\
\hline March 4, 1990 & $\begin{array}{l}\text { - Minor explosive event } \\
\text { - Lava dome collapse } \\
\text { - Ash plume to }>12,000 \text { meters } \\
\text { - Lahars and flooding in Drift River valley } \\
\text { - Sediment deposited in Drift River valley causes channel migration } \\
\text { and a large proportion of the flow is down Cannery Creek }\end{array}$ & Minutes to days \\
\hline March 9, 1990 & $\begin{array}{l}\text {-Minor explosive event } \\
\text { - Lava dome collapse } \\
\text {-Ash plume to } 10,000 \text { meters } \\
\text { - Lahars and flooding in Drift River valley }\end{array}$ & Minutes \\
\hline March 14, 1990 & $\begin{array}{l}\text { - Minor explosive event } \\
\text { - Lava dome collapse } \\
\text {-Ash plume to } 12,000 \text { meters } \\
\text { - Lahars and flooding in Drift River valley }\end{array}$ & Minutes \\
\hline March 23, 1990 & $\begin{array}{l}\text { - Minor explosive event } \\
\text { - Lava dome collapse } \\
\text {-Ash plume to }>10,000 \text { meters } \\
\text { - Pyroclastic flow } \\
\text { - Lahars and flooding in Drift River valley }\end{array}$ & Minutes \\
\hline March 29, 1990 & $\begin{array}{l}\text {-Minor explosive event } \\
\text { - Lava dome collapse }\end{array}$ & Minutes \\
\hline April 6, 1990 & $\begin{array}{l}\text { - Minor explosive event } \\
\text { - Lava dome collapse } \\
\text { - Ash plume to } 9,000 \text { meters } \\
\text { - Pyroclastic flow } \\
\text { - Lahars and flooding in Drift River valley }\end{array}$ & Minutes \\
\hline April 15, 1990 & $\begin{array}{l}\text { - Minor explosive event } \\
\text { - Lava dome collapse } \\
\text {-Ash plume to }>10,000 \text { meters } \\
\text { - Pyroclastic flow } \\
\text { - Lahars and flooding in Drift River valley }\end{array}$ & Minutes to hours \\
\hline April 21, 1990 & $\begin{array}{l}\text {-Minor explosive event } \\
\text { - Lava dome collapse } \\
\text { - Ash plume to }>8,000 \text { meters } \\
\text { - Pyroclastic flow } \\
\text { - Lahars and flooding in Drift River valley }\end{array}$ & Minutes to hours \\
\hline April 26, 1990 & $\begin{array}{l}\text { - Pyroclastic flow } \\
\text {-Minor ash emission } \\
\text { - Lahars and flooding in Drift River valley }\end{array}$ & Minutes \\
\hline
\end{tabular}




\section{HAZARDOUS PHENOMENA AT REDOUBT VOLCANO}

A volcanic hazard is any volcanic phenomenon that is potentially threatening to life or property. Hazards associated with volcanic eruptions at Redoubt Volcano are generally categorized as either proximal or distal (table 3). Proximal hazards are those phenomena that occur in the immediate vicinity of the volcano, typically within a few tens of kilometers of the active vent. This group of hazards is likely to, but may not always, result in death or injury to an individual within several kilometers of the vent, who would have no time to escape from the area in the event of an eruption. Distal hazards pose less risk to people because there could be adequate time for warn-

Table 3. Hazardous phenomena at Redoubt Volcano

\begin{tabular}{|c|c|c|c|c|}
\hline TYPE & $\begin{array}{l}\text { PROX- } \\
\text { IMAL }\end{array}$ & $\begin{array}{l}\text { DIS- } \\
\text { TAL }\end{array}$ & COMMENTS & CURRENT RISK \\
\hline $\begin{array}{l}\text { Volcanic } \\
\text { ash clouds }\end{array}$ & & $x$ & $\begin{array}{l}\text { Hazardous to aircraft and may } \\
\text { affect air travel hundreds to thou- } \\
\text { sands of miles from the volcano }\end{array}$ & $\begin{array}{l}\text { - Municipality of Anchorage } \\
\text { - Cook Inlet Region } \\
\text { - Areas "downwind" from the volcano }\end{array}$ \\
\hline $\begin{array}{l}\text { Volcanic } \\
\text { ash fallout } \\
\text { and } \\
\text { ballistics }\end{array}$ & $x$ & $x$ & $\begin{array}{l}\text { Could make breathing difficult } \\
\text { and interfere with the operation } \\
\text { of machinery and electrical } \\
\text { equipment. Heavy ashfall could } \\
\text { collapse structures. }\end{array}$ & $\begin{array}{l}\text { - Municipality of Anchorage } \\
\text { - Cook Inlet Region } \\
\text { - Areas "downwind" from the volcano }\end{array}$ \\
\hline $\begin{array}{l}\text { Lahars and } \\
\text { floods }\end{array}$ & $x$ & $x$ & $\begin{array}{l}\text { Fast-moving, high sediment con- } \\
\text { centrations, may transport boul- } \\
\text { der-sized particles. }\end{array}$ & $\begin{array}{l}\text { - Drift River Oil Terminal } \\
\text { - All stream valleys that head on } \\
\text { Redoubt Volcano } \\
\text { - Recreational use in or near rivers } \\
\text { and streams that flow from the vol- } \\
\text { cano }\end{array}$ \\
\hline $\begin{array}{l}\text { Pyroclastic } \\
\text { flows and } \\
\text { surges }\end{array}$ & $x$ & $x$ & Often very hot $\left(300\right.$ to $\left.>800^{\circ} \mathrm{C}\right)$ & $\begin{array}{l}\text { - Recreational use within about } 15 \\
\text { kilometers of the volcano } \\
\text { - No developments in range }\end{array}$ \\
\hline $\begin{array}{l}\text { Debris } \\
\text { avalanches }\end{array}$ & $x$ & $x$ & $\begin{array}{l}\text { May travel tens of kilometers } \\
\text { from the volcano }\end{array}$ & $\begin{array}{l}\text { - Drift River Oil Terminal (?) } \\
\text { - All stream valleys that head on } \\
\text { Redoubt Volcano } \\
\text { - Recreational use in or near rivers } \\
\text { and streams that flow from the vol- } \\
\text { cano }\end{array}$ \\
\hline $\begin{array}{l}\text { Directed } \\
\text { blasts }\end{array}$ & $x$ & & $\begin{array}{l}\text { May affect broad sectors of the } \\
\text { volcano }\end{array}$ & $\begin{array}{l}\text { - Recreational use within about } 5 \text { kilo- } \\
\text { meters of the volcano } \\
\text { - No developments in range }\end{array}$ \\
\hline $\begin{array}{l}\text { Volcanic } \\
\text { tsunamis }\end{array}$ & & $x$ & $\begin{array}{l}\text { Potential for generation is very } \\
\text { low }\end{array}$ & - Shoreline areas of Cook Inlet \\
\hline $\begin{array}{l}\text { Volcanic } \\
\text { gases }\end{array}$ & $x$ & & $\begin{array}{l}\text { Typically present in low concen- } \\
\text { trations }\end{array}$ & $\begin{array}{l}\text { - Recreational use in the active vent } \\
\text { area } \\
\text { - No developments in range }\end{array}$ \\
\hline
\end{tabular}


ing and evacuation. This group of hazards affects people and structures that are more than about 10 kilometers from the active vent. Some phenomena, such as volcanic ash, either in explosive eruption columns or ash clouds that drift far away from the volcano, can be both a proximal and a distal hazard.

The classification of hazardous phenomena at Redoubt Volcano as proximal or distal is only approximate because the extent of a particular hazard is in part related to the scale of the eruption. Thus, a large eruption may cause some phenomena to affect areas well beyond the volcano, whereas during a smaller, more typical eruption, the same phenomena may only affect areas in the immediate vicinity of the volcano.

\section{PRINCIPAL VOLCANIC HAZARDS}

\section{Volcanic Ash Clouds}

About 23 individual volcanic bursts caused by explosions, dome collapse, or both, occurred during the 1989-90 eruption of Redoubt Volcano. During some of these bursts, vertical clouds or plumes of fine volcanic ash were forcibly expelled into the atmosphere. Ash plumes reached altitudes of 7,000 to more than 12,000 meters above sea level before being dispersed by the prevailing winds (fig. 6). These ash clouds initially drifted to the northeast and east, but eventually moved to the southeast over Canada and into the airspace over the conterminous United States. At least one ash cloud from Redoubt Volcano reached as far as west Texas and the Gulf of Mexico (fig. 6; Casadevall, 1994a). Throughout the eruption, clouds of volcanic ash remained a serious threat to aircraft downwind from the volcano and at least seven commercial jet aircraft encountered ash clouds from Redoubt Volcano (table 4).
Volcanic ash from the 1989-90 eruption of Redoubt Volcano is composed of sand-sized and smaller particles of angular pumice, volcanic glass, crystals, and rock fragments. Volcanic ash clouds from Redoubt Volcano occupied a portion of the airspace utilized by jet aircraft and traveled at altitudes ranging from about 4,500 to 12,000 meters; Casadevall, 1994b). The ash may interfere with aircraft engine operation and electronic components and its abrasive quality often causes damage to the exterior of jet aircraft, especially the leading edges of wings and cockpit windshields (Casadevall, 1994b). Although the seriousness of the hazard from volcanic ash clouds depends on various characteristics of the plume-such as the concentration and size of ash particles, the rate of ascent, and the geometry of the plume-any ash cloud is potentially harmful to aircraft and should be avoided if possible.

The most serious volcanic ash aircraft encounter was on December 15, 1989, when a Boeing 747-400 approaching Anchorage International Airport with 231 passengers on board flew into the ash cloud about 240 kilometers northeast of the volcano. Power was lost in all four engines and the plane descended about 3,210 meters before the flight crew was able to restart the engines and avoid a crash (Casadevall, 1994a). Damage to the aircraft was about $\$ 80$ million (Brantley, 1990; Steenblik, 1990). On December 17, 1989 (35 to 55 hours after the December 15 eruption), a military and a commercial jet flying over west Texas (about 5,400 kilometers from Redoubt Volcano) encountered a Redoubt ash cloud (fig. 6). One jet experienced brief engine failure, the other experienced abrasion to the leading edges of the wings (Casadevall, 1994a).

In addition to the incidents described above, volcanic ash clouds from Redoubt Volcano curtailed activity at two other Anchorage area airports, Merrill Field and Elmendorf Air Force Base. Although no significant amount of ash fallout occurred, ash clouds in the air- 

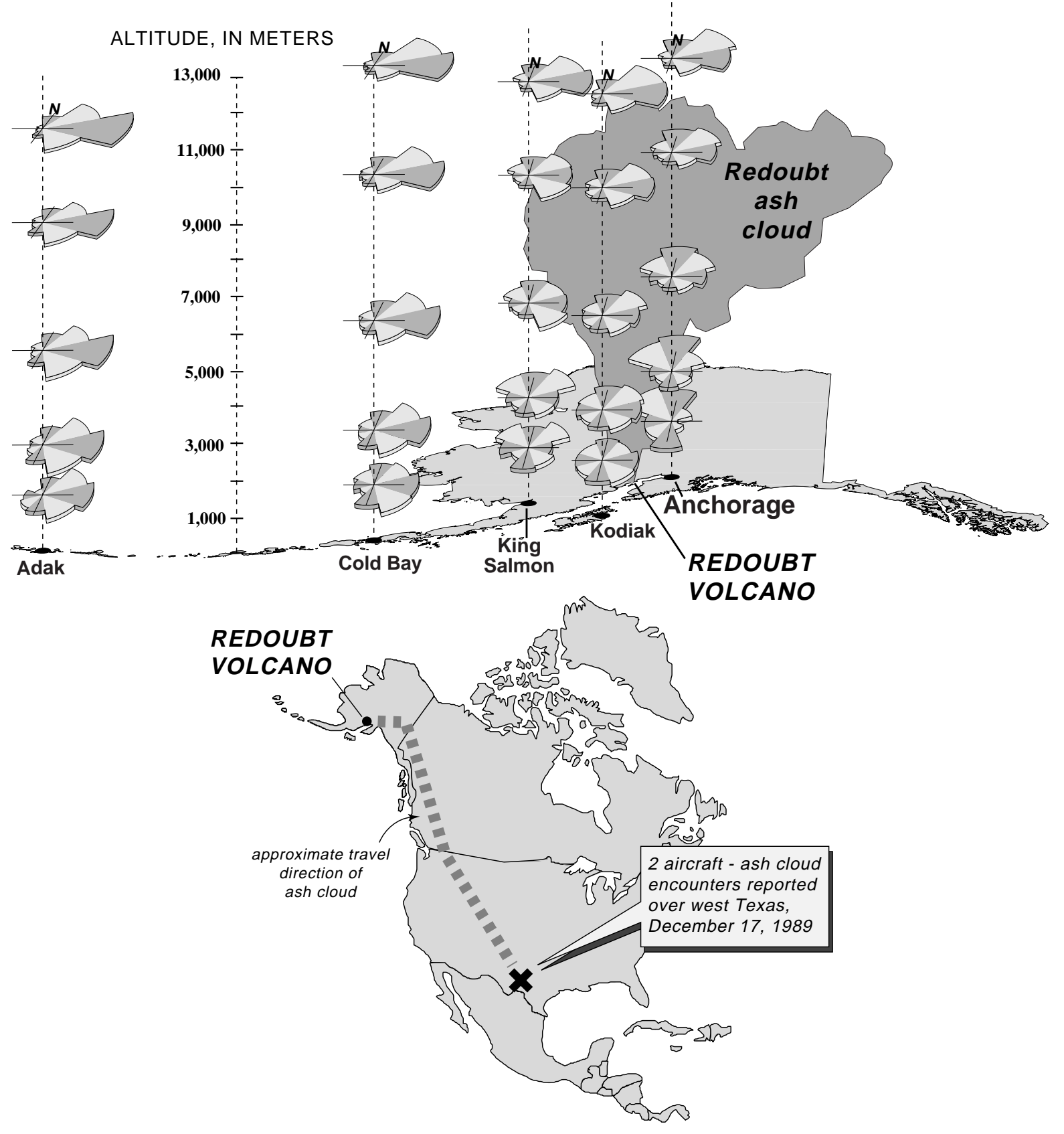

Figure 6. Average wind direction and likely travel paths for volcanic ash clouds from Redoubt Volcano. Adak data from 1952-1962; Cold Bay data from 1945-1957; King Salmon data from 1953-1960; Kodiak data from 1949-1962; Anchorage data from 1948-1972. Original data from the National Climatic Data Center, National Oceanic and Atmospheric Administration. Windrose -section lengths are proportional to wind frequency determined by annual percent. Lower map shows probable track of Redoubt ash cloud encountered by jet aircraft over west Texas about 5,400 kilometers from Redoubt Volcano and 35 to 55 hours after the December 15, 1989 eruption. 
Table 4. Aircraft-ash encounters during the 1989-90 eruption of Redoubt Volcano (from Casadevall, 1994a)

\begin{tabular}{|c|c|c|c|}
\hline DATE & LOCATION & DESCRIPTION OF ENCOUNTER & DAMAGE \\
\hline $\begin{array}{l}\text { Dec. } 15 \\
1989\end{array}$ & $\begin{array}{l}\text { Near } \\
\text { Anchorage, } \\
\text { Alaska }\end{array}$ & $\begin{array}{l}\text { Boeing } 737 \text { encounters ash cloud in darkness at } \\
5,200 \text { meters altitude during approach to Anchorage } \\
\text { International Airport }\end{array}$ & $\begin{array}{l}\text { - Abraded and dulled wind- } \\
\text { shield } \\
\text { - Leading edges of wings } \\
\text { abraded }\end{array}$ \\
\hline $\begin{array}{l}\text { Dec. } 15 \\
1989\end{array}$ & $\begin{array}{l}\text { Near } \\
\text { Anchorage, } \\
\text { Alaska }\end{array}$ & $\begin{array}{l}\text { Boeing } 727 \text { encounters ash cloud between } 4,600 \text { to } \\
5,500 \text { meters altitude. Aircraft returns to Anchorage. }\end{array}$ & - No report of damage \\
\hline $\begin{array}{l}\text { Dec. } 15 \\
1989\end{array}$ & $\begin{array}{l}\text { Near } \\
\text { Anchorage, } \\
\text { Alaska }\end{array}$ & $\begin{array}{l}\text { Boeing } 747-400 \mathrm{KLM} \text { flight } 867 \text { encounters ash cloud } \\
\text { at 7,600 meters altitude during descent toward } \\
\text { Anchorage International Airport } \\
\text { - After flying through the ash cloud, all } 4 \text { engines stall } \\
\text { - The aircraft glided without power for about } 4 \text { min- } \\
\text { utes } \\
\text { - After reaching about } 5,200 \text { meters, two of the } \\
\text { engines were restarted, and about } 4 \text { minutes later } \\
\text { the remaining two engines were restarted } \\
\text { - The fully powered aircraft landed safely at Anchor- } \\
\text { age International Airport about } 15 \text { minutes after } \\
\text { the scheduled arrival time }\end{array}$ & $\begin{array}{l}\text { - Severe abrasion of the exte- } \\
\text { rior of the aircraft and all four } \\
\text { engines; the engines were } \\
\text { replaced before the aircraft } \\
\text { was flown again } \\
\text { - Avionics and electrical com- } \\
\text { ponents badly damaged } \\
\text { - Engine oil, hydraulic fluid, } \\
\text { and potable water supply } \\
\text { contaminated by ash } \\
\text { - Total cost to repair aircraft } \\
\text { about } \$ 80 \text { million dollars }\end{array}$ \\
\hline $\begin{array}{l}\text { Dec. } 16, \\
1989\end{array}$ & $\begin{array}{l}\text { Near } \\
\text { Anchorage, } \\
\text { Alaska }\end{array}$ & $\begin{array}{l}\text { Boeing } 737 \text { encounters ash cloud soon after takeoff } \\
\text { from Anchorage International Airport }\end{array}$ & $\begin{array}{l}\text { - Cockpit windshield severely } \\
\text { abraded and required } \\
\text { replacement } \\
\text { - Engines were inspected and } \\
\text { cleaned }\end{array}$ \\
\hline $\begin{array}{l}\text { Dec. } 17 \\
1989\end{array}$ & $\begin{array}{l}\text { Near } \\
\text { El Paso, } \\
\text { Texas }\end{array}$ & $\begin{array}{l}\text { Boeing } 727 \text { encounters ash cloud over west Texas } \\
\text { between } 11,000 \text { and } 8,800 \text { meters altitude while } \\
\text { descending for landing } \\
\text { - Power in one engine lost }\end{array}$ & - No report of damage \\
\hline $\begin{array}{l}\text { Dec. } 17 \\
1989\end{array}$ & $\begin{array}{l}\text { Near } \\
\text { El Paso, } \\
\text { Texas }\end{array}$ & $\begin{array}{l}\text { U.S. Navy DC-9 encounters ash cloud at about } 8,000 \\
\text { meters during climb to cruising altitude }\end{array}$ & $\begin{array}{l}\text { - Leading edges of wings } \\
\text { abraded } \\
\text { - Engines inspected but no } \\
\text { damage reported }\end{array}$ \\
\hline $\begin{array}{l}\text { Feb. 21, } \\
1990\end{array}$ & $\begin{array}{l}\text { Near } \\
\text { Anchorage, } \\
\text { Alaska }\end{array}$ & $\begin{array}{l}\text { Boeing } 727 \text { encounters ash cloud in darkness between } \\
5,500 \text { and } 6,100 \text { meters altitude about } 12 \text { minutes after } \\
\text { takeoff from Anchorage International Airport }\end{array}$ & $\begin{array}{l}\text { - Cockpit windshield and lead- } \\
\text { ing edges of wings abraded } \\
\text { - Engines were not damaged }\end{array}$ \\
\hline
\end{tabular}

space over the Anchorage area and beyond caused numerous flight cancellations, delays, and route changes. During December 1989, more than 90 military cargo flights were diverted from Elmendorf Air Force Base and about 45 flights by military turboprop aircraft were cancelled (Casadevall, 1994a). As a result of the 1989-90 eruption, lost revenue at Anchorage International Airport was about \$2.6 million (Casadevall, 1994a).

\section{Volcanic Ash Fallout}

As clouds of volcanic ash drift away from the volcano, a steady rain or fallout of ash may occur. Volcanic ash is one of the most troublesome and hazardous products of explosive volcanism and because it may be transported long distances, it has the potential to affect areas many hundreds of kilometers from the volcano. Fortunately, few people have ever been 
killed by the direct affects of falling ash although the weight of a thick ash fall could cause structures to collapse and inhaling ash particles poses a health hazard.

Blocks or bombs of volcanic rock debris may be ejected as ballistic projectiles that fall or strike areas near the vent. During the most vigorous part of the eruption on December 15, 1989, pumice fragments up to 10 centimeters in diameter were falling about 40 kilometers east (downwind) of the volcano. Typically, the zone of bomb fallout is within 10 to 15 kilometers of the vent and long-distance transport is relatively uncommon. Thus, people, structures, or low-flying aircraft would be at risk only if they were about 15 kilometers or less from the vent.

Ashfall from the 1989-90 eruptions was a serious public health concern for parts of south-central Alaska, especially the Kenai Peninsula. During periods of continuous ash fallout, the public was advised to remain indoors and wear dust masks. Many schools were closed, and some individuals experienced respiratory problems. The municipal airport at Kenai was closed for several days as a result of ash fallout from the January 8, 1990 eruption. Gas-powered turbines at the Beluga power plant, the primary power supply for Anchorage, were shut down in anticipation of the adverse effects of a thick ashfall on February 24,1990 . Only one of the turbines remained in operation for a brief period during the ashfall, but fortunately there were no interruptions in power service.

The approximate extent of ash fallout from the 1989-90 eruptions is shown on figure 7 . Although older deposits of Redoubt tephra

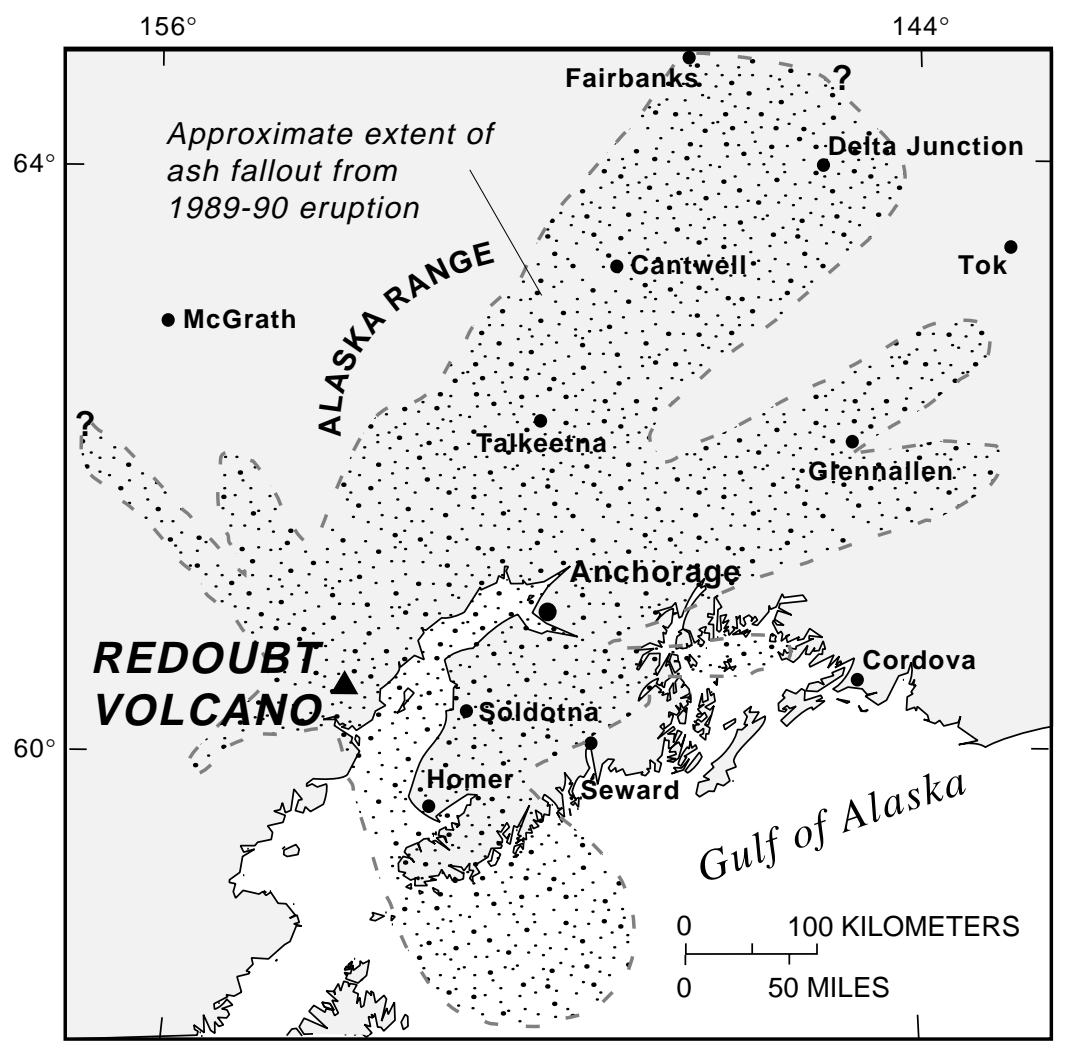

Figure 7. Approximate extent of volcanic ash fallout from the 1989-90 eruption of Redoubt Volcano, (modified from Scott and McGimsey, 1994). 
have been found near the volcano and in lake sediments on the Kenai Peninsula, Redoubt tephra deposits have not yet been found beyond the limits of the 1989-90 tephra fall. Thus, it is impossible to estimate with certainty how extensive the tephra fallout would be should a much larger eruption take place. The ash fallout hazard zone indicated on figure 8 shows areas that could be affected by ash fallout from an eruption similar to the 1989-90 event. Because wind direction and speed will control the movement of the ash plume, the areas most likely to receive ashfall are those in the zone of prevailing winds. The strongest and most consistent winds are from the west, southwest, and northwest (fig. 6); thus, areas east, northeast, and southeast of the volcano are most likely to receive ash fallout from future eruptions. Facilities in the upper Cook Inlet region such as oil drilling rigs, oil refineries, manufacturing plants, and power plants could be affected by ashfall.

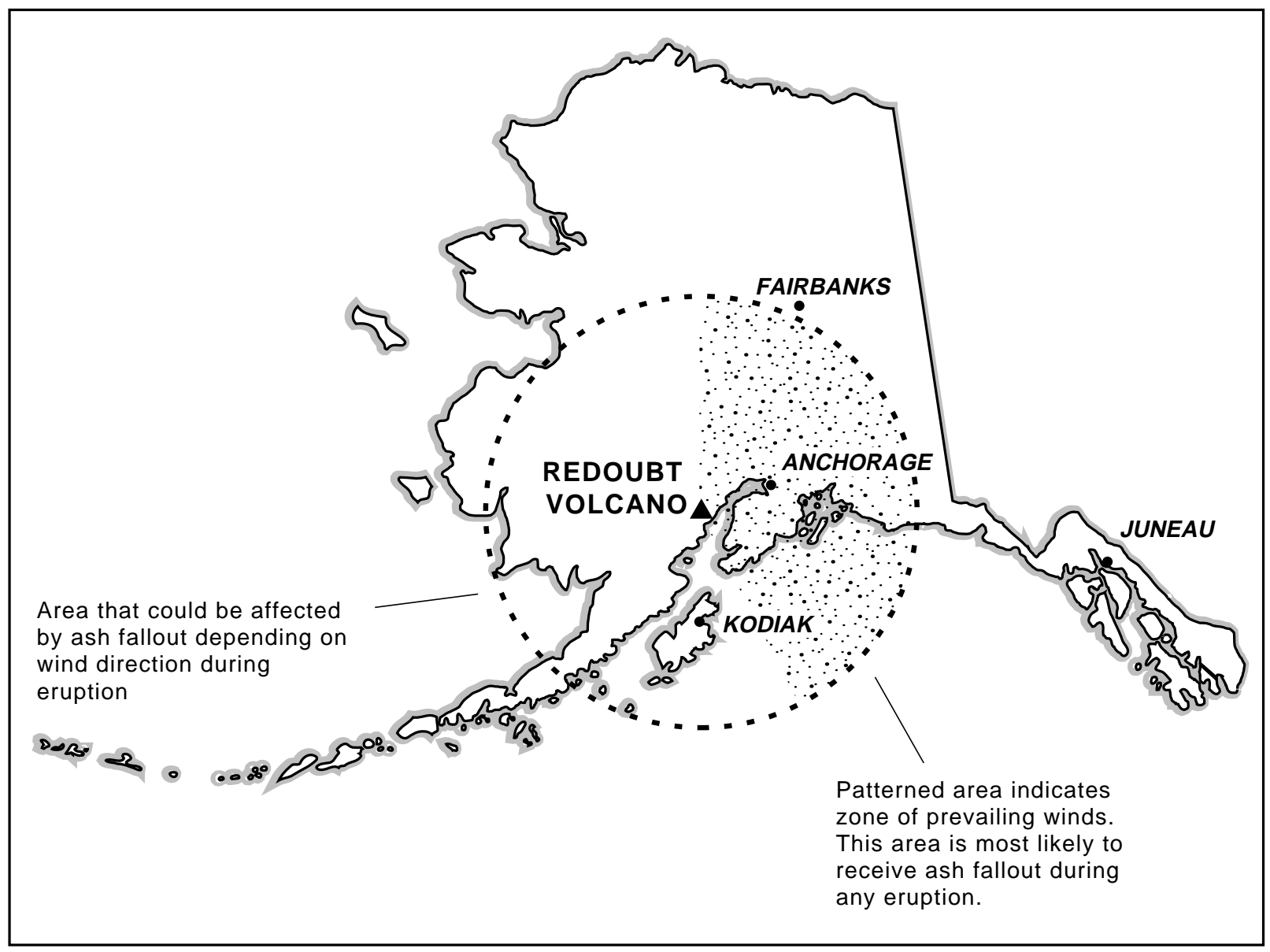

Figure 8. Area likely to be affected by volcanic ash fallout from eruptions similar to the 1989-90 eruption of Redoubt Volcano. 


\section{Lahars, Lahar-Runout Flows, and Floods}

Most of the volcanoes in Alaska are mantled with variable amounts of ice and snow and have significant amounts of unconsolidated volcanic debris on their flanking slopes. Because eruptive materials are hot, melting of the ice and snowpack can result. The meltwater mixes with available unconsolidated sediment and forms various types of flowage phenomena. Most of these phenomena are categorized as debris flows or more specifically as lahars. Typically, lahars consist of boulders, sand, and silt, but commonly they undergo downstream transformation to finer grained flows, sometimes referred to as hyperconcentrated flows or lahar-runout flows. If enough sediment is lost from the lahar during flowage, the lahar may transform into a normal streamflow or flood and consist mostly of water.

During the 1989-90 eruptions of Redoubt Volcano, hot pyroclastic flows melted significant parts of the Drift Glacier and the winter snowpack. Some of the ensuing lahars, laharrunout flows, and floods completely inundated the Drift River valley, threatened the Drift River Oil Terminal and eventually flowed into Cook Inlet about 35 kilometers downstream from the volcano (fig. 9). At least six lahars in the Drift River reached Cook Inlet during the 1989-90 eruptions (Dorava and Meyer, 1994). The largest of these occurred on January 2, 1990 and inundated Rust Slough, including parts of the Drift River Oil Terminal. At the oil terminal, muddy sediment about 1 meter thick was deposited by this lahar. As the 1989-90 eruptions progressed, additional sediment was delivered to the lower Drift River, Rust Slough, and Cannery Creek by lahars and lahar-runout flows (fig. 10). This caused the braided channel of the Drift River to change its course repeatedly, temporarily increasing the discharge of tributary streams and accelerating erosion. As a result of this process, increased flow in Montana Bill Creek (fig. 9) initiated bank erosion that exposed, but did not rupture, a buried oil pipeline that crosses Montana Bill Creek north of the oil terminal (Dorava and Meyer, 1994).

The 1989-90 eruption began in December at a time when the amount of snow and ice on the volcano was significantly greater than it would be in March and April. Thus, the initial lahars were larger than those that formed later in the eruption. As the eruption progressed, Drift Glacier became deeply scoured and lesser amounts of snow and ice were available for melting by the hot pyroclastic flows, even though some of these flows were larger but less hot than those that were generated earlier in the eruption. As the amount of snow and ice available for scour and entrainment by the pyroclastic flows decreased, so did the size of the resultant lahars.

Lahars from prehistoric eruptions have been identified in the Crescent River drainage, on the south side of Redoubt Volcano (fig. 9; Riehle and others, 1981; Begét and Nye, 1994). Like the 1989-90 lahars that inundated the Drift River, the Crescent River deposits also extend to the coastline (fig. 9). Radiocarbon dates on buried wood and peat associated with the Crescent River lahars indicate that they were deposited since about 3,900 years ago (Begét and Nye, 1994). As many as seven separate lahars are present in the Crescent River valley; however, the deposits exposed along the North Fork (the "North Fork lahars" of Begét and Nye, 1994) may be closely spaced in time and do not necessarily indicate separate eruptions (Begét and Nye, 1994). The matrix material in these deposits contains very little clay, and some of the larger volcanic clasts exhibit reddish alteration rinds and prismatic fractures (Begét and Nye, 1994). According to Begét and Nye (1994), these characteristics are indicative of lahar deposition while the lahar is still hot, thus linking the lahar deposit directly with an eruption. Conversely, the lahar deposit at the mouth of Cres- 


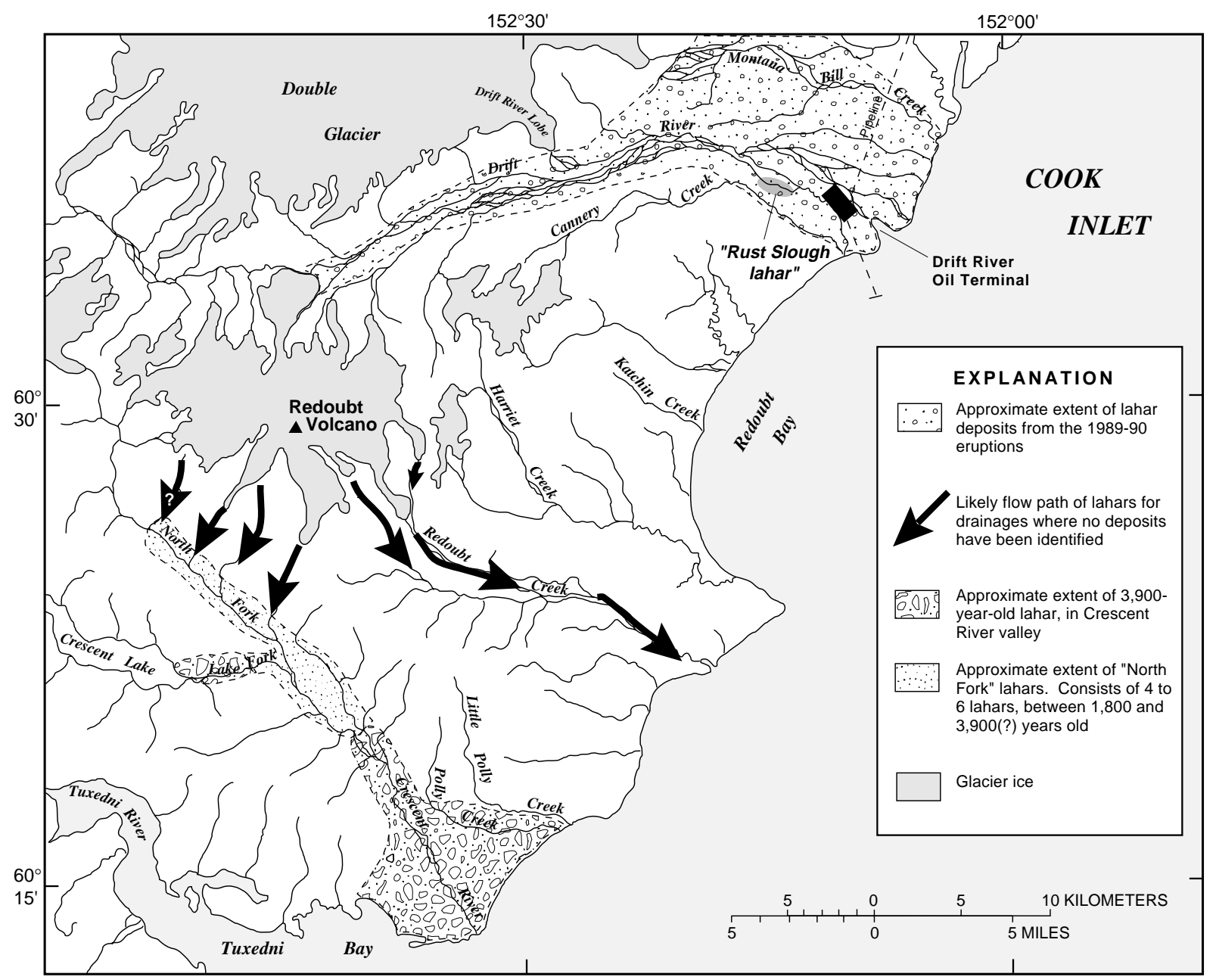

Figure 9. Areas likely to be affected by lahars, lahar-runout flows, and floods during eruptions of Redoubt Volcano. Valleys could be inundated across their entire width. Where the flows are channelized, flow velocity and depth will be the greatest (modified from Begét and Nye, 1994, and Dorava and Meyer, 1994).

cent River (the "Crescent River lahar" of Begét and Nye, 1994) contains altered rock debris, has clay in the matrix, and lacks abundant prismatically fractured clasts. This deposit may record a large-scale slope failure of the southern flank of Redoubt Volcano that transformed into a lahar by the addition of water (Begét and Nye, 1994). It is not necessarily related to an eruption, although an eruption could certainly trigger a massive slope failure as at Mt. St. Helens in 1980 (Voight and others, 1981). If the "Crescent River lahar" can not be linked to an eruption of Redoubt Volcano, it would rep- resent a different type of volcanic hazard: one that could occur at any time due to unstable slope conditions or a large tectonic earthquake and without the usual precursory eruptive signals such as increased seismicity, tephra, and gas emission.

An additional lahar deposit (the "Rust Slough lahar") is present along the lower part of Rust Slough, a few kilometers northwest of the Drift River Oil Terminal (fig. 9; Begét and Nye, 1994). This 2-3-meter thick deposit has abundant clay in the matrix, contains altered volcanic rock fragments, is pervasively oxi- 


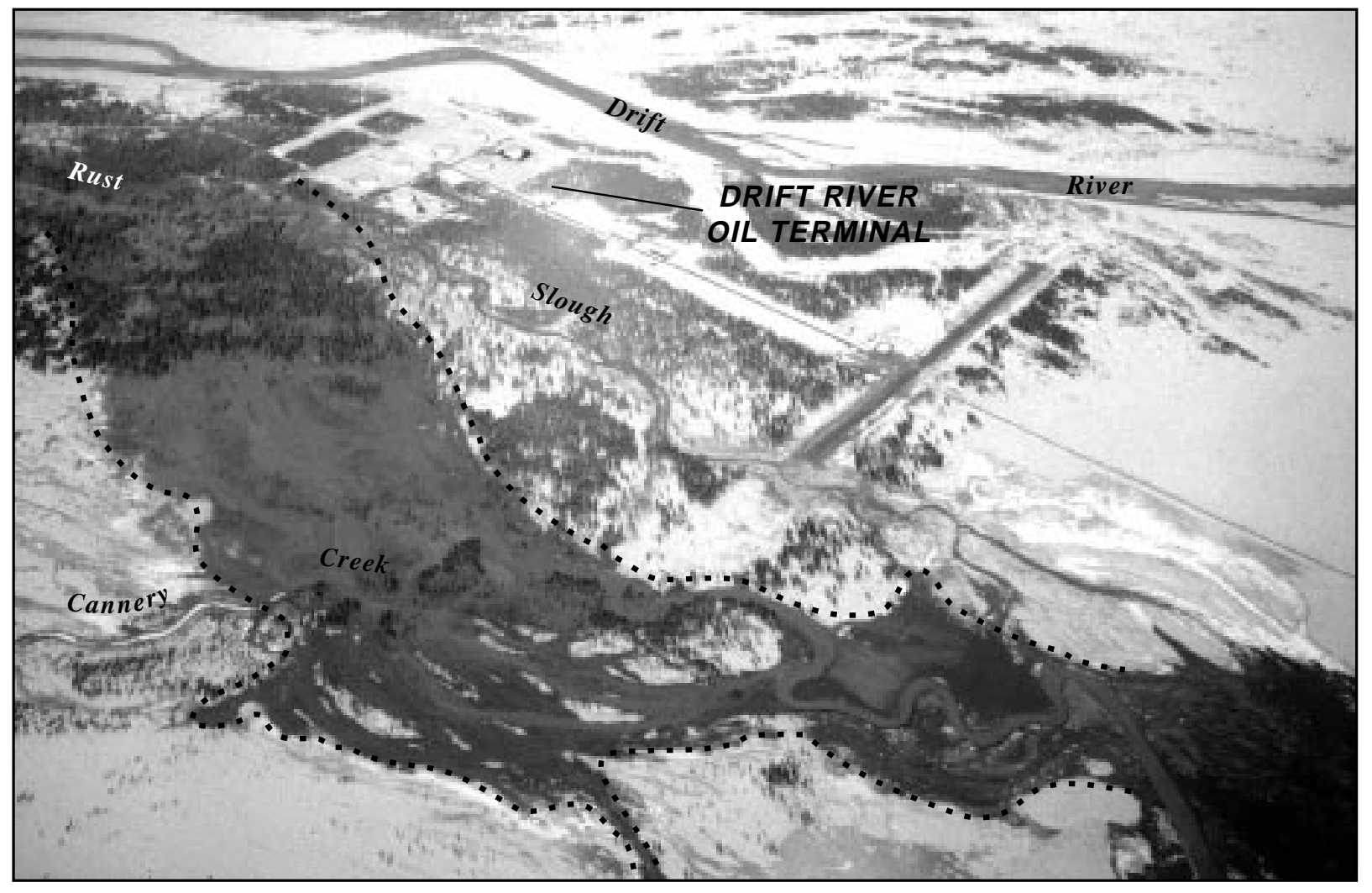

Figure 10. Drift River Oil Terminal and lahars (outlined) in Rust Slough, March 23, 1990. (Photograph by E.W.Wolfe, USGS.)

dized, and has a distinctive yellowish color. Although the Rust Slough lahar has not been studied in detail, its altered character suggests that it may have formed by downstream transformation of a debris avalanche to a lahar, brought about by a large-scale flank collapse of Redoubt Volcano. Radiocarbon dating of organic remains found immediately above and below the lahar indicate that it was deposited between about 1000 and 200 years before present (Begét and Nye, 1994). A similar, and perhaps correlative lahar deposit, is present upstream from the Drift Glacier piedmont lobe (Begét and Nye, 1994).

During the 1965-68 and 1989-90 eruptions, the upper third of the Drift Glacier was removed by the explosive effects of these erup- tions while the lower part of the glacier remained a stagnant piedmont lobe (fig. 11). After the 1965-68 eruptions, reestablishment of the Drift Glacier on the upper slopes of Redoubt Volcano eventually allowed the regenerated portion to reconnect with the stagnant piedmont lobe. This process initiated a pulse of rapid ice flow (a kinematic wave of thickening ice) that moved through the piedmont lobe (Sturm and others, 1986, 1988; Trabant and Meyer, 1992). Where the Drift River flows across the terminus of Drift Glacier, the valley is narrow and the river is confined to a deep gorge of bedrock on the north and glacier ice on the south. It was feared that, subsequent to the 1965-68 eruption, the advancing piedmont lobe would close off the Drift River, thereby 


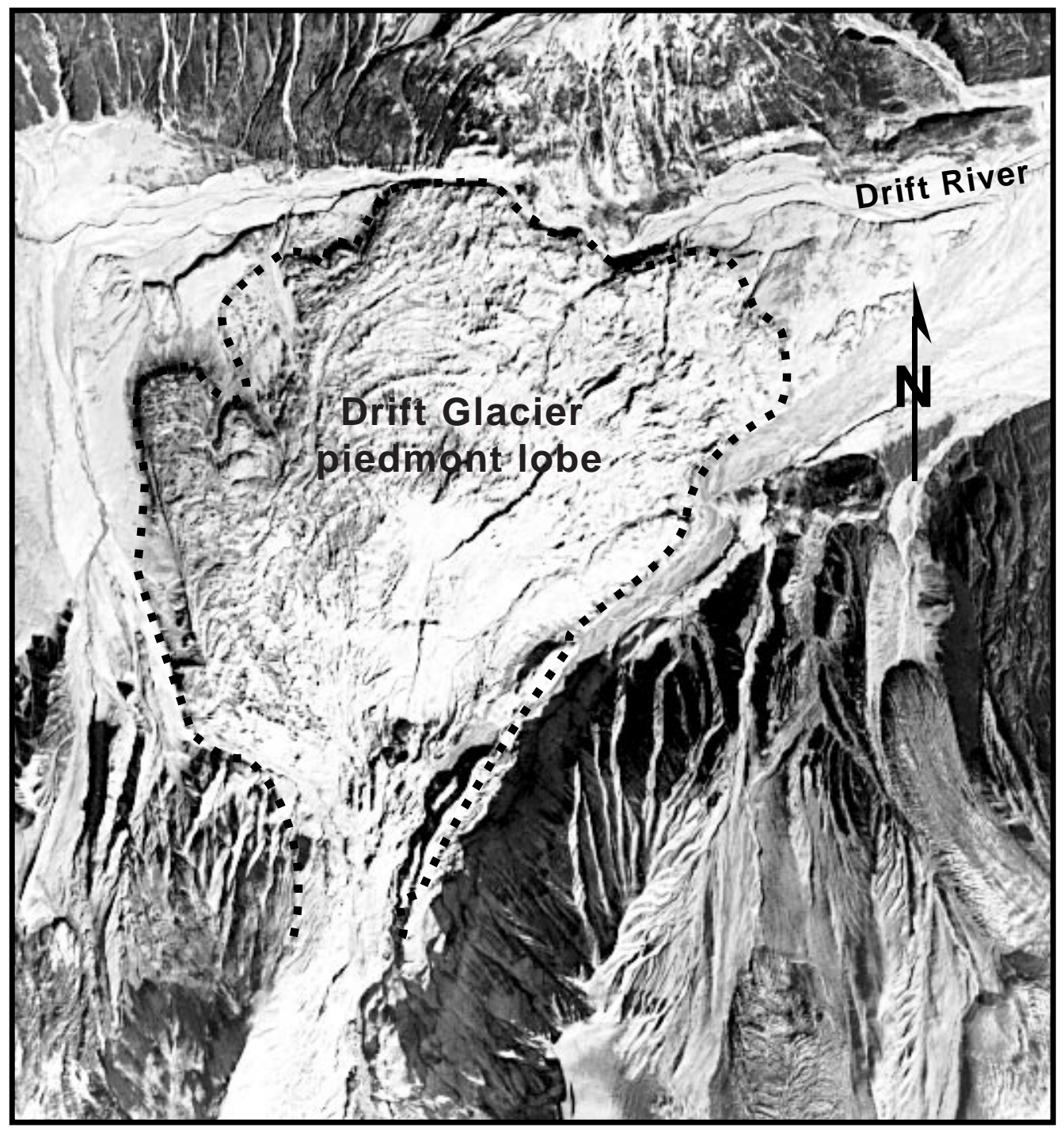

Figure 11. Vertical aerial photograph of Drift Glacier piedmont lobe. This part of the glacier was virtually all that remained after the 1989-90 eruption.

creating an unstable glacier-dammed lake upstream from the glacier (fig. 12) which would pose a significant flood hazard to the Drift River Oil Terminal 35 kilometers downstream. Glacier-dammed lakes are prone to failure, especially if the glacier impounds a large volume of water. Typically, the ice dam fails rapidly, and the resulting flood may be large. Fortunately, the kinematic wave that propagated through Drift Glacier subsequent to the 1965-68 eruption did not result in an advance of the Drift Glacier across Drift River and no ice dam was formed. However, the present regrowth of glacier ice on the volcano could initiate another kinematic wave through the stagnant piedmont lobe, and the potential for an ice dam forming across the Drift River may increase in the next 10 to 15 years. 


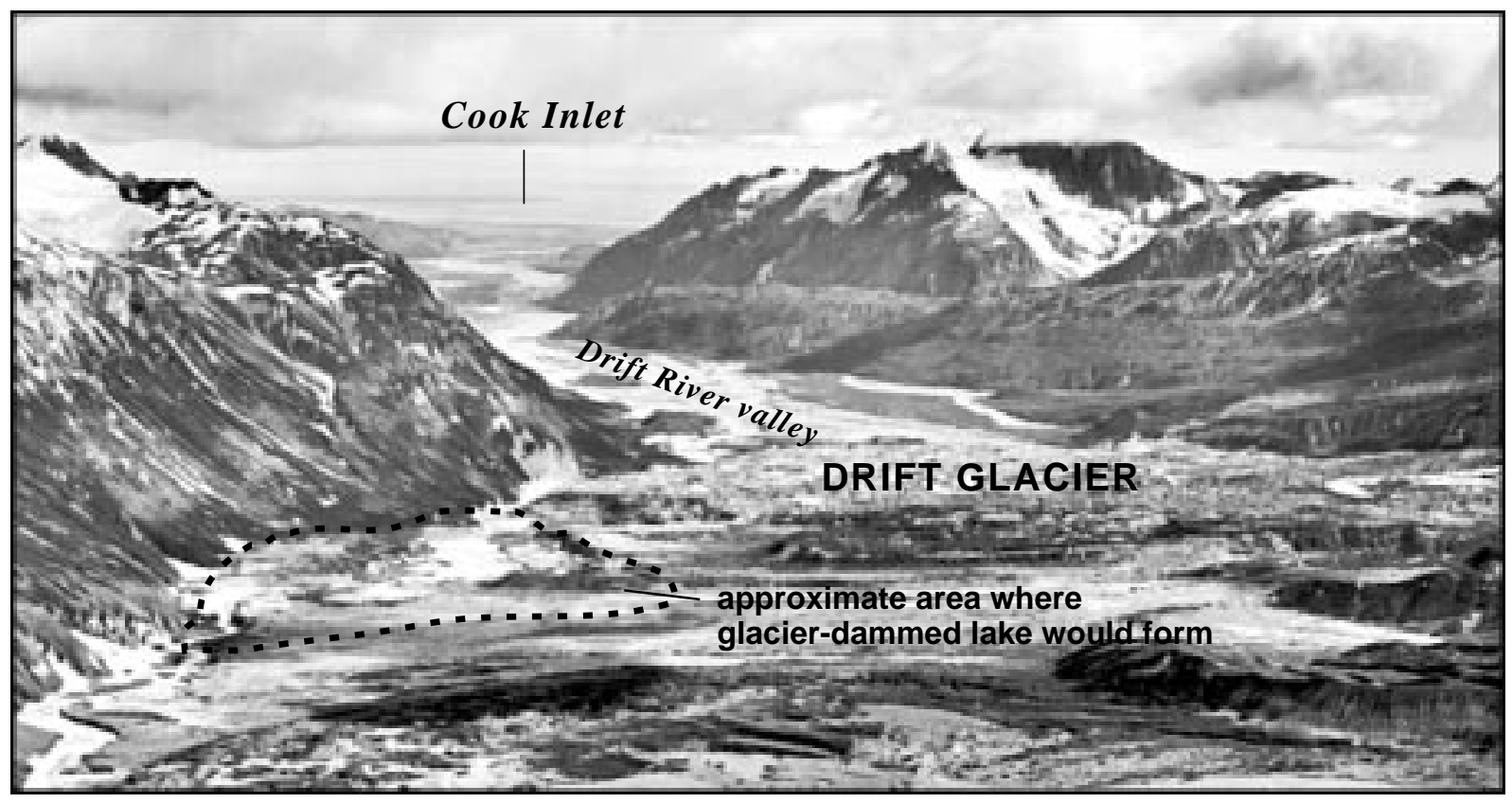

Figure 12. Drift Glacier area. View is downstream to the northeast. (Photograph by Austin Post, USGS, August 30, 1984.)

Assuming that a glacier dam could form subsequent to an eruption (fig. 13), the ice dam would be no more than 50 meters high and would impound about 7,000,000 cubic meters of water. Using a dam-break model (Fread and others, 1991) and assuming that the ice dam fails rapidly to the full depth of the lake (a worst-case, and possibly unrealistic situation), the maximum possible discharge at the ice dam could be about 44,200 cubic meters per second. A flood of this size would quickly entrain sediment from the Drift River valley, possibly increasing its volume substantially as the flow transformed from a flood flow to a lahar or lahar-runout flow. Such a flow could pose a threat to the Drift River Oil Terminal. Flow depths at the oil terminal would be at least as great as those during the 1989-90 eruptions, but they probably would not exceed the 5 to 6 meters of protection provided by the concrete-lined dike surrounding the tank farm.
A more realistic situation is slow failure of the ice dam. If the ice dam fails slowly, the peak discharge at the dam would be less, and in the range of 500 to 1000 cubic meters per second. A flood of this size would likely remain channelized, and pose little hazard to the Drift River Oil facility unless major channel shifting occurs.

When there is adequate time for warning and when people in river valleys and low-lying areas understand that they are at risk, lahars are seldom fatal. However, in some areas, development along rivers and streams that drain volcanoes has proceeded unchecked mainly because the severity of the lahar hazard was or is not recognized. Furthermore, valley bottoms are often good places for building structures and facilities. As a result, the risk from lahars and floods conflicts with the need for economic development. 


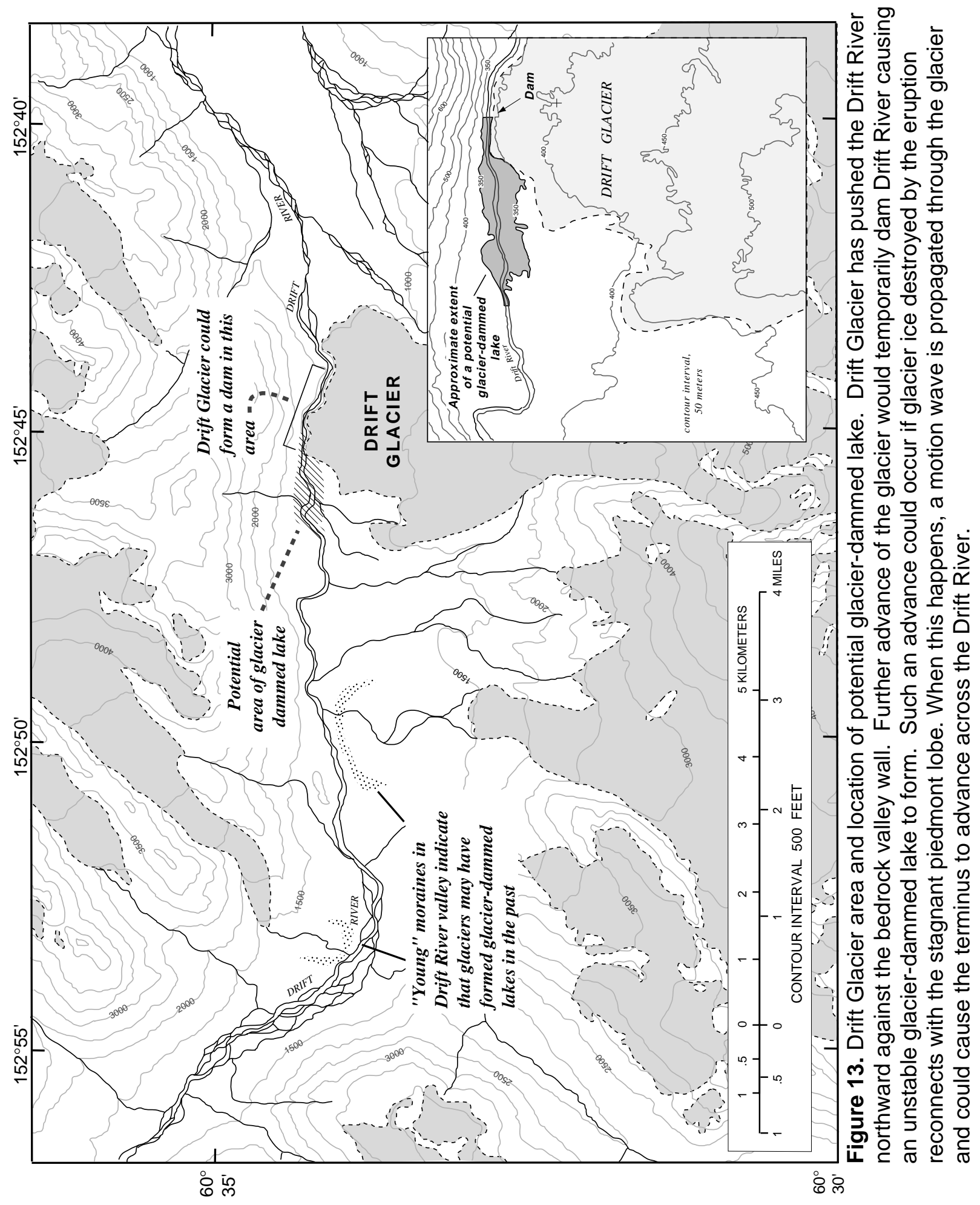




\section{Pyroclastic Flows}

During the 1989-90 eruptions, pyroclastic flows were formed primarily by repeated collapse of a lava dome (Gardner and others, 1994). Fourteen distinct lava domes formed over the active vent during the course of the eruption as viscous lava was slowly extruded (Miller, 1994). As the domes were being extruded, they became oversteepened and then failed by gravitational collapse (fig. 14). The collapse caused a sudden release of pressure from the upper part of the magma chamber which explosively propelled hot gas, water vapor, and rock debris down the slope of the volcano. The resultant pyroclastic flows and associated ash clouds were directed down the east side of Drift Glacier and the Drift River valley, traveling about 8 kilometers downstream from the volcano.

The pyroclastic flows generated by the 1989-90 eruptions melted and scoured large portions of Drift Glacier. Because the glacier was heavily crevassed and steep, the hot pyroclastic flows incised ice canyons through the glacier, some as large as 40 meters deep and 30 meters wide. This led to the development of lahars downstream from Drift Glacier as meltwater mixed with debris deposited at the distal end of Drift Glacier by the pyroclastic flows.

Pyroclastic flows from most future eruptions at Redoubt Volcano would be expected to reach at least several kilometers to tens of kilometers of the vent and should be directed along the major valleys that radiate from the

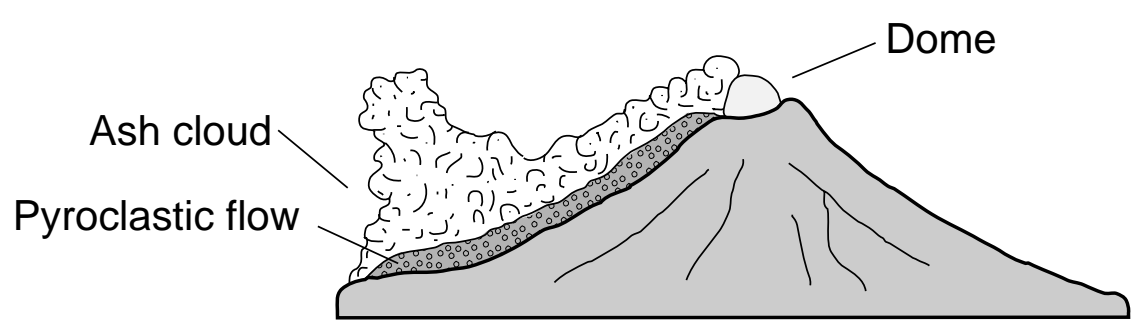

Explosive dome collapse

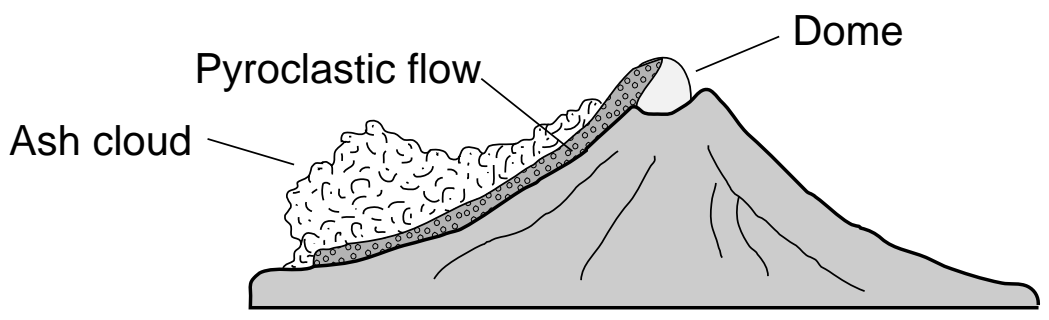

Gravitational dome collapse

Figure 14. Types of dome collapse. Pyroclastic flows at Redoubt Volcano are caused primarily by collapse of the lava dome (modified from Cas and Wright, 1987). 
volcano. Pyroclastic flow deposits of unknown, but probably Holocene age, are present along the North Fork of the Crescent River near the base of Redoubt Volcano (Begét and Nye, 1994). These deposits are about 15 kilometers from the summit, indicating that during at least one pre-historic eruption, pyroclastic flows were able to reach at least this far. Because geologic mapping and identification of pyroclastic flow deposits older than 1989-90 is generally limited at Redoubt Volcano, we are not confident that geologic evidence sufficiently portrays the hazard.

However, we can consider the run-out length of pyroclastic flows from other similar volcanoes as a preliminary basis for hazard zonation. Using data from Hayashi and Self (1992) a regression equation relating run-out length to vent height (we assume vent height = summit height for Redoubt Volcano) is used to predict the travel distance of future pyroclastic flows at Redoubt Volcano (fig. 15). This is the basis for the hazard zone boundary on the map

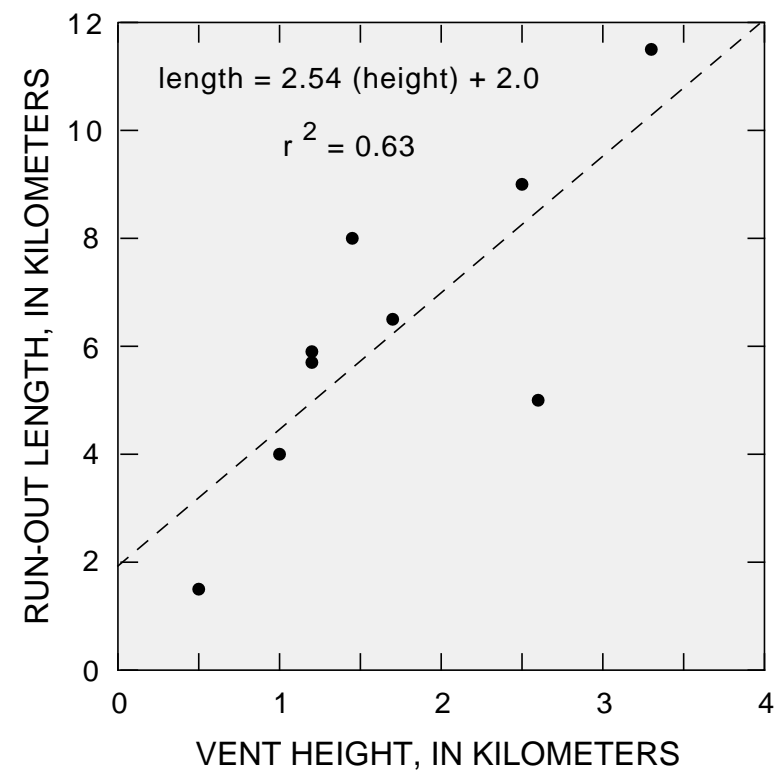

Figure 15. Pyroclastic flow run-out length as a function of vent height for small pyroclastic flows (data from Hayashi and Self, 1992) showing pyroclastic flow hazards (fig. 16). Note that about 50 percent of the area within the zone most likely to be affected by pyroclastic flows contains some glacier ice. If large, hot, pyroclastic flows are directed down any of the glaciated drainages, melting of ice and snow is expected and downstream flooding could result.

\section{Pyroclastic Surges}

During the February 15, 1990 eruption of Redoubt Volcano, a pyroclastic surge climbed a ridge 700 meters above the terminus of Drift Glacier and about 10 kilometers from the dome, charring woody vegetation, melting cables to seismic monitoring equipment, and partially burning a ptarmigan (figs. 16 and 17; Gardner and others, 1994). Had the ridge not been an obstacle in the flow path, the surge probably would have travelled much farther from the volcano. It is difficult to accurately predict the extent of a pyroclastic surge. However, because of their genetic relation to pyroclastic flows, they have a slightly larger lateral extent. Thus, we are uncertain about the extent of the hazard boundary (fig. 16). Because surges are typically hot $\left(300\right.$ to $\left.800{ }^{\circ} \mathrm{C}\right)$ and gaseous, death or injury from asphyxiation and burning may result. Because the surge cloud may travel very fast (at least tens of meters per second) pre-eruption evacuation is the only way to alleviate the risk posed by pyroclastic surges. For Redoubt Volcano, the area that could be reached by a surge is uninhabited and therefore pyroclastic surges are not a great hazard away from the volcano itself. 


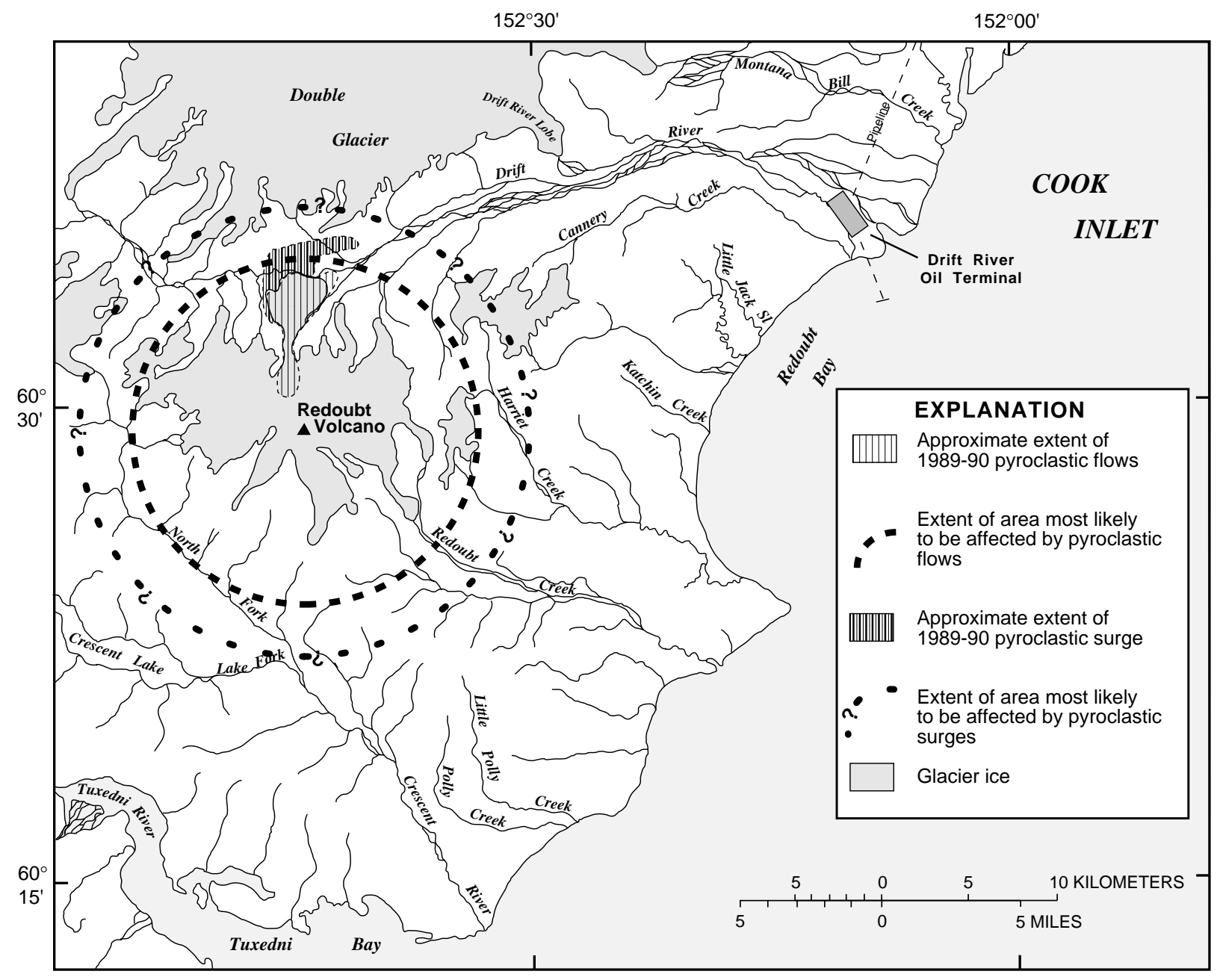

Figure 16. Area most likely to be affected by pyroclastic flows and surges during eruptions of Redoubt Volcano. Also shown is the extent of pyroclastic flows and surges from the 1989-90 eruptions (from Gardner and others, 1994).

\section{OTHER HAZARDOUS PHENOMENA}

\section{Debris Avalanches}

Volcanic debris avalanches commonly form by some type of structural collapse of the upper part of the volcano. The resulting debris avalanche deposit is usually recognized by its hummocky surface morphology and broad areal extent. At some volcanoes, debris avalanche deposits are traceable up the slopes of the volcano to a horseshoe-shaped scar at or near the volcano summit that marks the zone of collapse and origin of the debris avalanche.

A debris avalanche deposit from Redoubt Volcano has been identified along the coastline at Harriet Point, south of the Drift River Oil Terminal (fig. 18; Begét and Nye, 1994). The deposit extends into the sea several kilometers from the coast and apparently traveled down the valley of Redoubt Creek a distance of about 32 kilometers. The debris avalanche is thought to have been deposited between 


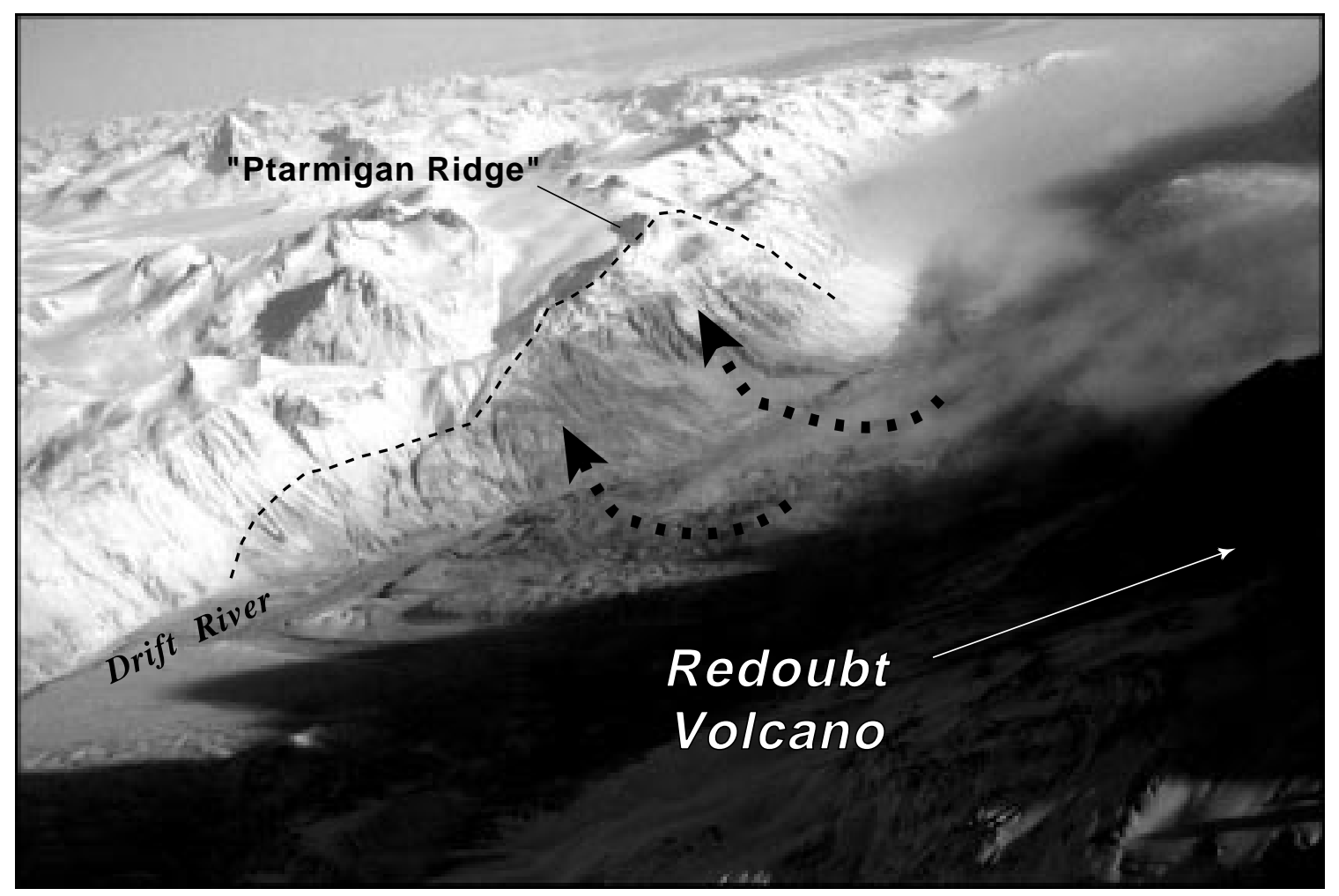

Figure 17. Approximate extent of pyroclastic surge deposits (dashed line) on Ptarmigan Ridge (unofficial name) north of Redoubt Volcano. Arrows indicate flow path down Drift Glacier and up Ptarmigan Ridge. (Photograph by C. A. Gardner, USGS, February 15, 1990.)

10,500 and 13,000 years before present and is the largest known volcanic debris avalanche in the Cook Inlet area (Begét and Nye, 1994).

The debris avalanche deposit at Harriet Point is evidence that volcanic debris avalanches are a potential hazard at Redoubt Volcano. Using data summarized by Hayashi and Self (1992), a plot of run-out distance versus volcano height was constructed (fig. 19). A linear regression line through these data yields a simple relation for making preliminary estimates of debris avalanche runout based on the height of the volcano. For Redoubt Volcano, the estimated run-out distance is about 34 kilometers. However, many of the factors relevant to debris avalanche motion are not considered in such a relation, and the technique is only a crude approximation for flowage over land. Thus, the hazard zone boundaries indicated on figure 18 are preliminary, and run-out distances greater than this may be possible.

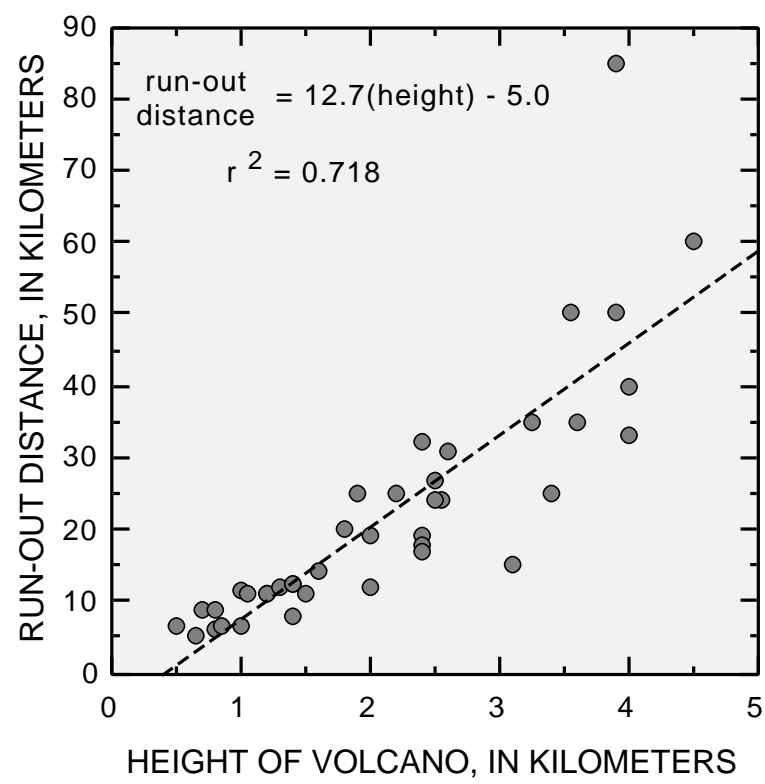

Figure 19. Run-out distance as a function of volcano height for volcanic debris avalanches (data from Hayashi and Self, 1992). 


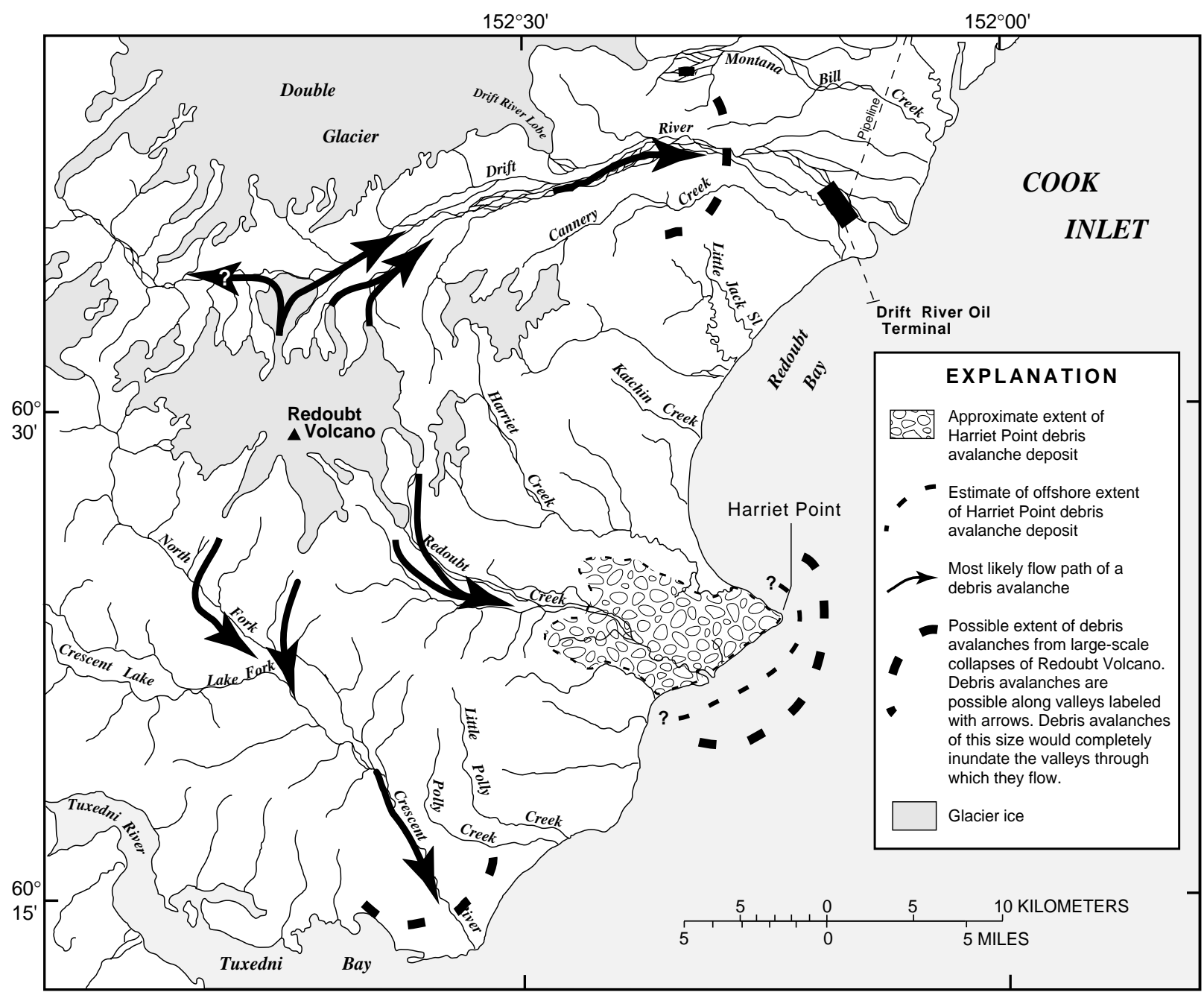

Figure 18. Areas most likely to be affected by large-scale debris avalanches. Extent of Harriet Point debris avalanche deposit from Begét and Nye, 1994.

\section{Directed Blasts}

A directed blast is a large-scale lateral volcanic explosion caused by a major landslide or slope failure. Although geologic studies are not complete, no evidence of directed blasts has been found at Redoubt Volcano. The hazard zone boundary showing the area most likely to be affected by a directed blast (fig. 20) is based on data from the 1980 eruption of Mt. St. Helens and the 1956 eruption of Bezymianny Volcano in Russia. Directed blasts associated with erup- tions at these two volcanoes are among the largest known and thus are "worst case" examples. If a directed blast were to occur from the present summit dome, it could affect a broad area, possibly a $180^{\circ}$ sector from the dome. A directed blast will usually happen in the first few minutes of an eruption and thus there is no time for warning or evacuation. Living things and structures in the path of a directed blast will be killed or destroyed by impact, burning, abrasion, burial, and heat. 


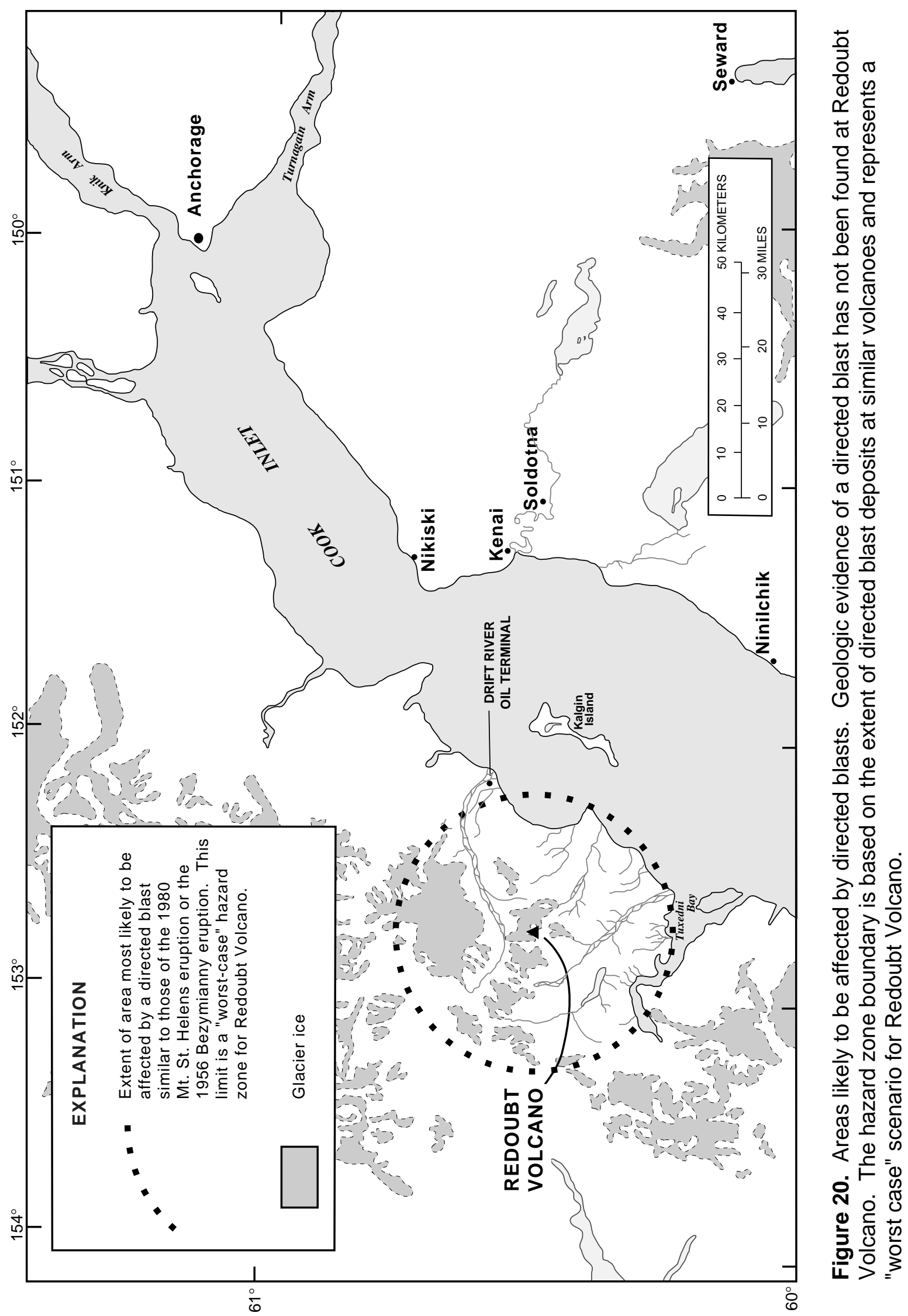




\section{Tsunamis}

Volcanoes that are situated near or on the coastline are potentially capable of initiating tsunamis. Of 69 well-studied volcanigenic tsunamis, 22 percent were caused by earthquakes associated with eruptions, 20 percent were caused by pyroclastic flows entering the water, 19 percent were caused by submarine explosions, 12 percent were caused by volcanic debris avalanches (both hot and cold), 9 percent were caused by caldera collapse, 7 percent were caused by pyroclastic surges, about 10 percent were caused by lahars and air waves from explosions, and 1 percent were caused by lava avalanching into the sea (Latter, 1981, p. 470).

Lahars and debris avalanches associated with historic and pre-historic eruptions at Redoubt Volcano have been sufficiently mobile to flow several tens of kilometers and reach the sea. The lahars that reached the coast along Drift River during the 1989-90 eruptions flowed passively into Cook Inlet and did not initiate even a small tsunami. Because these lahars were relatively thin and only moving a few meters per second, they were not capable of rapidly displacing a significant volume of water in Cook Inlet.

A 10,500 - to 13,000 -year-old debris-avalanche deposit at the mouth of Redoubt Creek, south of Harriet Point (Begét and Nye, 1994), indicates that large debris avalanches occur at Redoubt Volcano (fig. 18). Hummocky terrain immediately offshore from the "Harriet Point debris avalanche" is probably the seaward extent of the avalanche deposit indicating that the debris avalanche flowed into Cook Inlet after traveling about 30 kilometers down the valley of Redoubt Creek. It is difficult to estimate the size of a wave(s), if any, the Harriet Point debris avalanche would have generated when it flowed into Cook Inlet. The water immediately offshore from Harriet Point is shallow and ranges in depth from 6 to 20 meters. At the time of the avalanche, global sea level was still depressed several tens of meters because a significant amount of fresh water still remained in Pleistocene glaciers. Possibly the debris avalanche never flowed into the waters of Cook Inlet. Moreover, if a wave had been generated, it would have been highly localized, and would not have affected a broad area, except perhaps Kalgin Island (fig. $21)$. If the same volume debris avalanche or even a significantly larger one occurred today, it would not displace much water.

Future lahars moving down the Crescent River valley also are unlikely to initiate tsunamis. The water depth within the first few kilometers offshore from the mouth of Crescent River is only about 5 meters deep. Thus only a small amount of water is capable of being displaced. Furthermore, a lahar entering Cook Inlet at the mouth of Crescent River would be moving relatively slowly over a low gradient, highly irregular surface. Under these conditions, a tsunami initiated by a lahar in the Crescent River valley is unlikely.

\section{Volcanic Gases}

Gases are emitted by most active volcanoes, because magma contains dissolved gases and boils off shallow ground water that is typically present within volcanoes. The most common volcanic gases are water vapor, carbon dioxide, carbon monoxide, sulfur dioxide, and hydrogen sulfide. Volcanic sulfur and halide gases that encounter water form large amounts of sulfuric acid $\left(\mathrm{H}_{2} \mathrm{SO}_{4}\right)$ and minor amounts of hydrochloric $(\mathrm{HCl})$ and hydrofluoric acid (HF) as aerosols or droplets. Both carbon monoxide and carbon dioxide are colorless and odorless and thus impossible to detect without some kind of measuring device. Although carbon dioxide is not toxic, it is heavier than air and may displace the available oxygen in confined spaces or low-lying areas causing suffocation. In high concentrations, both hydrogen sulfide 


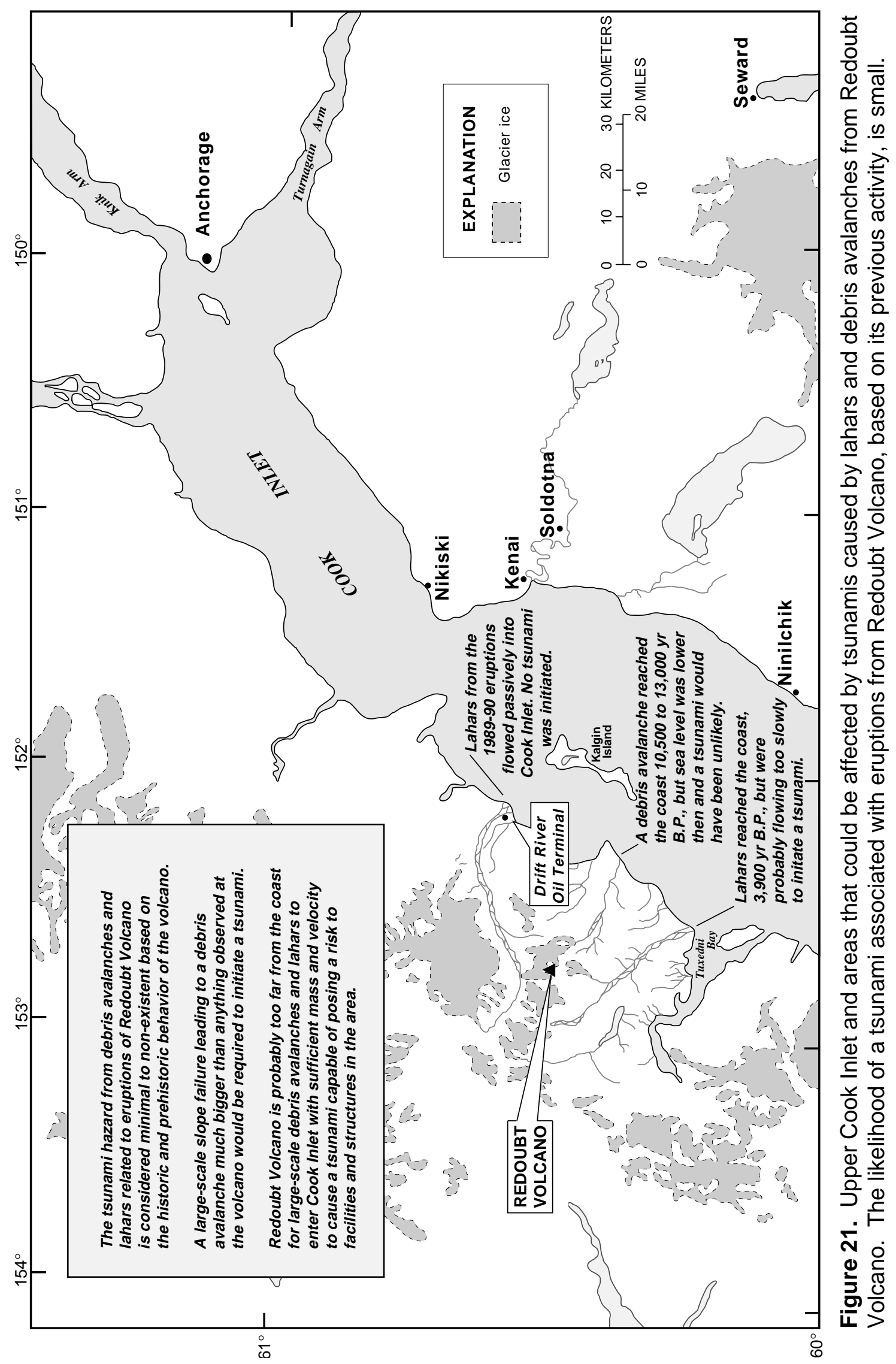


and sulfur dioxide may be harmful or toxic to humans and may damage crops and vegetation downwind from the volcano. Acid precipitation may develop from the mixing of snow or rain with acidic volcanic aerosols, which may cause various types of skin and respiratory irritations and corrosive damage to paint, fabric, and structures. Wind tends to disperse volcanic gas and it is typically not found near the ground in concentrations hazardous to humans or animals more than about 10 kilometers from the volcano. During large eruptions, significant volumes of gas can travel high in the atmosphere downwind from the volcano for days and thousands of kilometers.

At Redoubt Volcano, existing data on concentrations of sulfur dioxide, carbon dioxide, and hydrochloric acid are for areas directly over the volcano within a few kilometers of the vent (Casadevall and others, 1994). During a large eruption, the emission rate and concentration of volcanic gases will be high. However, the hazard from volcanic gases is unlikely to be greater than that posed by other volcanic phenomena. During non-eruptive periods, emission of volcanic gases may pose a health concern to someone actually in the active vent area; however, frequent windy conditions on Redoubt Volcano and the absence of an efficient trapping mechanism preclude localized buildup of volcanic gas.

\section{EVENT FREQUENCY AND RISK AT REDOUBT VOLCANO}

This report outlines the types of hazardous phenomena that could occur during an eruption of Redoubt Volcano, based on the longterm geologic and recorded history of eruptions. Because our knowledge of the eruptive history is preliminary, our assessment of the hazards at Redoubt Volcano is based, in part, on the behavior and eruptive style of other similar volcanoes for which there is more information. Although describing the extent and character of volcanic hazards provides useful information for understanding what might happen to people and property during the next eruption, the timing and magnitude of the next eruption are unknown.

Redoubt Volcano will erupt explosively in the future. The potential for encounters between jet aircraft and clouds of volcanic ash are likely to be the primary hazard associated with future eruptions. All aircraft downwind from the volcano are at risk from effects of volcanic ash. The frequency at which dangerous clouds of volcanic ash from any one eruption are produced cannot be estimated with certainty. Signs of volcanic unrest will precede an eruption of Redoubt Volcano. However, it is not possible to determine the size of an ash cloud before an eruption occurs, except that it will likely be similar to those of previous eruptions (e.g., 1989-90).

The only facility presently at risk from future eruptions of Redoubt Volcano is the Drift River Oil Terminal. The primary hazards threatening this facility are lahars, lahar-runout flows, and floods. During the 1989-90 eruption, sediment deposited by lahars along the lower part of the Drift River caused the channel to aggrade, resulting in flooding of the terminal area (fig. 22). By August 1990, continued channel aggradation caused partial diversion of the Drift River, and between 40 and 60 percent of the flow was in Montana Bill Creek (fig. 22). This resulted in channel and bank erosion of Montana Bill Creek, and the buried pipeline that feeds Drift River Oil Terminal from the north was exposed and at risk of being damaged or broken (Dorava and Meyer, 1994).

Lahars formed throughout the eruption, especially during the early phases when the snowpack and ice cover were greater than they were later. The largest lahar occurred on January 2, 1990 after a major explosive eruption. The estimated discharge of this lahar was as much as 100 times larger than the 100-year 


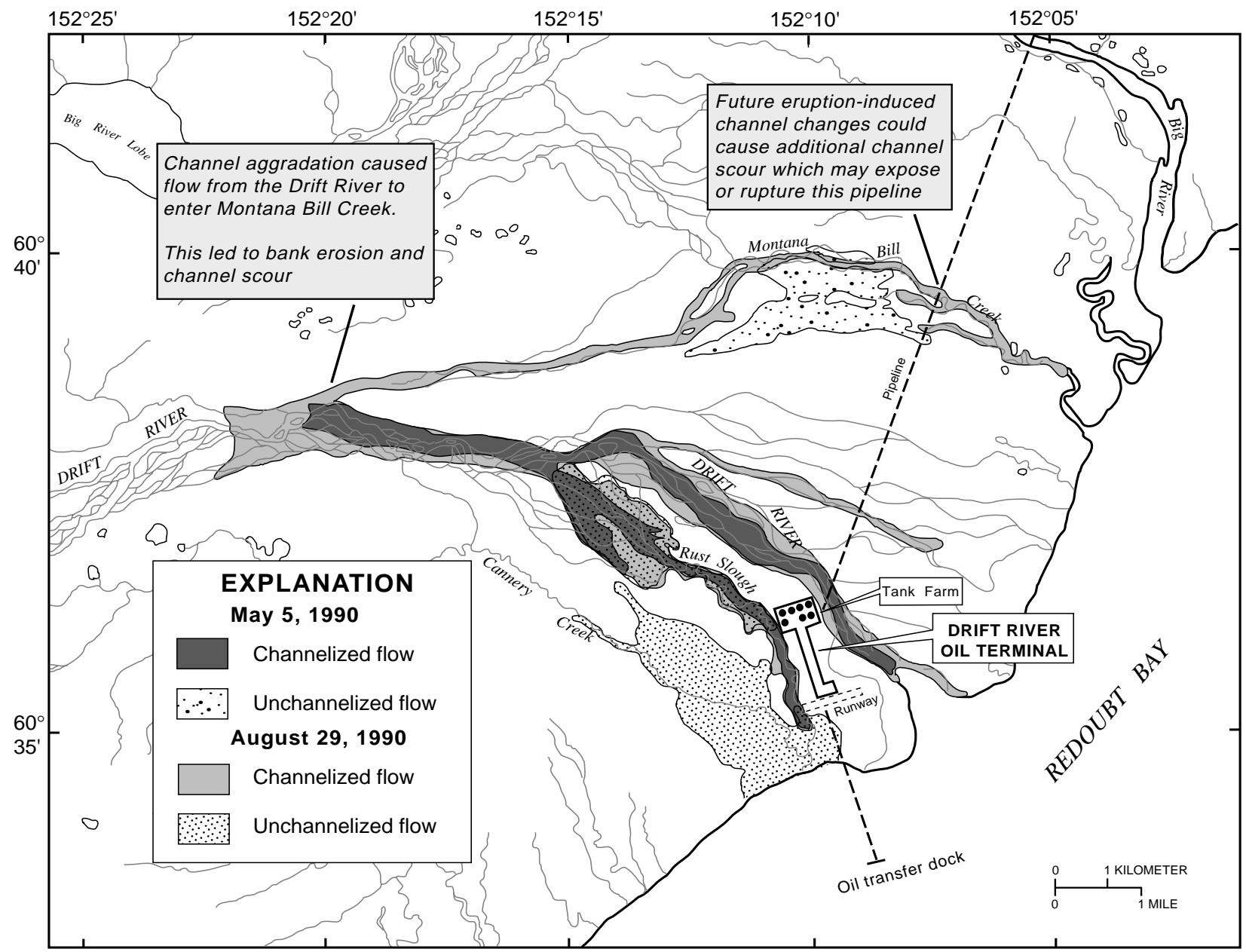

Figure 22. Areas of the lower Drift River alluvial fan that were inundated by floods in May August, 1990 after the eruption. Sediment delivered to the lower Drift River by lahars caused these changes. Flow velocity and depth are generally greater in areas of channelized flow and thus, these areas may be prone to bank erosion and channel scour (Modified from Dorava and Meyer, 1994).

flood expected on the Drift River (Dorava and Meyer, 1994). Future eruptions are likely to initiate lahars in the Drift River drainage basin; some of these flows are expected to reach the Drift River Oil Terminal. Following the 198990 eruptions, the existing system of dikes and levees at the Drift River Oil Terminal was enlarged and reinforced to prevent future inundation and erosion by lahars and floods. The dike and levee system will divert flows similar to and slightly larger than the January 2, 1990 flow away from oil storage facilities and inhibit channel bank erosion. 


\section{ECONOMIC EFFECTS}

The 1989-90 eruptions of Redoubt Volcano caused numerous short-term economic losses. Personnel from the Drift River Oil Terminal were evacuated three times and some support facilities were damaged. Several oil-drilling platforms in Cook Inlet were shut down, resulting in severely curtailed oil production and economic losses (Brantley, 1990).

Emission of tephra during many of the larger eruptive events, especially in December 1989 and January 1990, caused numerous problems for the airline industry. Hundreds of flights were cancelled and Anchorage International Airport experienced a revenue shortfall of about \$2.6 million (Brantley, 1990). Damage to aircraft was significant and the Boeing 747-400 that flew into the ash plume as it was attempting to land at Anchorage International Airport sustained about $\$ 80$ million in engine and structural damage (Steenblik, 1990). The total economic impact of the 1989-90 eruptions on the aviation industry was estimated at about \$101 million (Tuck and Huskey, 1992, 1994).

Other economic losses are difficult to quantify; however, all residents of south-central Alaska were in some way affected by the eruptions. The combination of delayed or cancelled air travel, temporary shutdowns of oil production facilities, school closures, public health concerns associated with ash fallout, and the general difficulties and disruption of daily life affected everyone in the region.

\section{HAZARD WARNING AND MITIGATION}

One of the primary roles of the Alaska Volcano Observatory (AVO) is to communicate timely warnings of volcanic unrest and potential eruptions (Eichelberger and others, 1995, p. 4). AVO monitors Redoubt Volcano with a real-time seismic network (fig. 23) equipped with an alarm system that is triggered by elevated levels of seismic (earthquake) activity indicating volcanic unrest. When volcanic unrest is detected, other monitoring techniques, such as satellite observations, measurement of volcanic gas flux, remote observation with real-time video or time-lapse cameras, and geodetic surveying, are usually employed to develop a comprehensive assessment of the likelihood of an eruption and its potential affects.

AVO distributes by fax and electronic mail, a weekly update of volcanic activity that summarizes the status of the more than 40 historically active volcanoes along the Aleutian arc. During periods of unrest or volcanic crises, updates are issued more frequently to advise the public of significant changes in activity. Recipients of these updates include the Federal Aviation Administration, the National Weather Service, the Alaska Department of Emergency Services, local military bases, the Govenor's office, various State offices, television and radio stations, news wire services, air carriers, and others. Updates also are distributed by electronic mail to various volcano information networks.

During the 1989-90 Redoubt eruptions, AVO developed a "level of concern color code" (Brantley, 1990; fig. 24). This code provides efficient and simple information about the status of volcanic activity or unrest and conveys AVO's interpretation of that activity or unrest in terms of the potential for eruptive activity and its likely effects. In the advent of a volcanic crisis, various Federal, State, and local officials are contacted by telephone, advised of the situation, and the level of concern color code is established while an update is being prepared. This approach was successfully used during the 1989-90 eruptions of Redoubt Volcano and the 1992 eruptions of Mount Spurr Volcano (Miller and Chouet, 1994; Keith, 1995). 


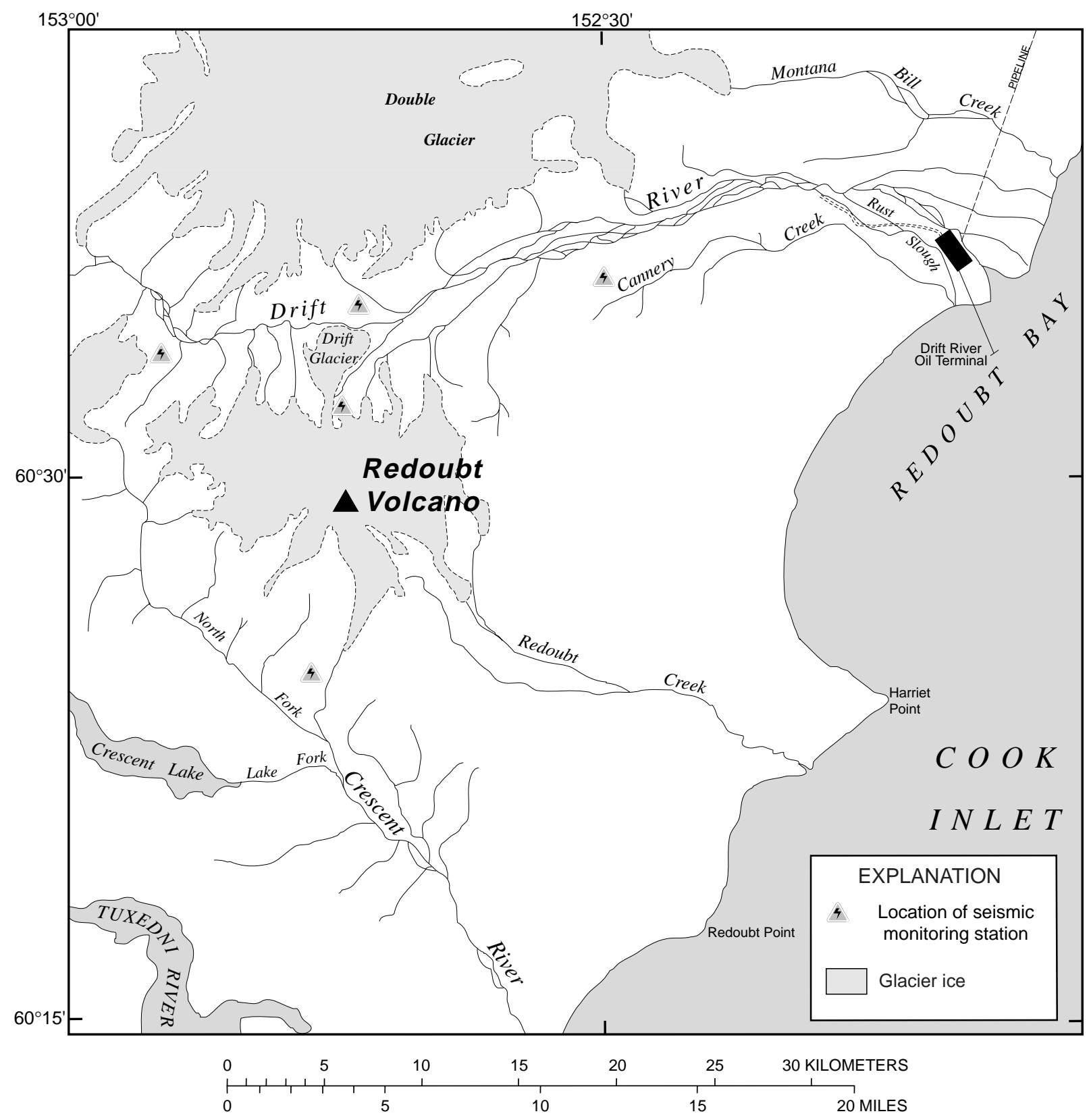

Figure 23. Location of seismic monitoring network on Redoubt Volcano. These stations provide real-time data on earthquakes beneath the volcano. The data are used to estimate the degree of volcanic unrest.

Minimizing the risks posed by eruptions of Redoubt Volcano is possible through adequate warning of potential hazards, such as drifting ash clouds and fallout, and by avoiding development or utilization of areas likely to be affected by future eruptions. Since Redoubt Volcano and much of the surrounding area is within Lake Clark National Park (fig. 2), development on or around the volcano is unlikely. If for some reason, development is 


\section{LEVEL OF CONCERN COLOR CODE}

To more concisely describe our level of concern about possible or ongoing eruptive activity at an Alaskan volcano, the Alaska Volcano Observatory (AVO) uses the following color-coded classification system. Definitions of the colors reflect AVO's interpretations of the behavior of the volcano. Definitions are listed below followed by general descriptions of typical activity associated with each color.

\section{GREEN: Volcano is in its normal "dormant" state.}

\section{YELLOW: Volcano is restless.}

Possible precursor volcanic activity is occurring (increased seismicity, anomalous steam plume). An eruption (explosive or non-explosive) is possible over the next few weeks and may occur with little or no additional warning.

ORANGE:

Explosive (or non-explosive) eruption is possible within a few days; non-explosive eruption may be occurring at present.

Strong increase in precursor activity. Explosive eruption may occur with little or no additional warning. Extrusion of lava dome or lava flow may be occurring.

RED:

Major explosive eruption is in progress or expected within 24 hours.

Explosive eruption is confirmed or expected shortly. Potentially hazardous ash plume to 25,000 feet above sea level or more is expected or has been confirmed.

Figure 24. Alaska Volcano Observatory's level of concern color code. This code and eruption updates are distributed to government agencies, the media, airlines, and the public.

unavoidable in hazardous areas, engineering measures may be employed to minimize or prevent undesirable consequences such as was done for the Drift River Oil Terminal. Although the present eruptive style indicates that the flowage hazard is mainly for the Drift River basin, future developments in other drainages that head on the volcano and coastal areas where these drainages enter Cook Inlet also could be at risk.
Knowledge of potential hazards is required to assess the risk associated with a specific location on or near the volcano and whether or not movement to another location would be safer. Recreational users of the area are advised that low-lying terrain along rivers and streams draining the volcano are subject to lahars, lahar-runout flows, and floods. In the event of an eruption, movement to "higher" ground could provide adequate protection (fig. 
25). However, significant hazards still exist from airborne debris, especially in areas close to or downwind from the volcano. During an eruption, access closer than about 10 kilometers from the volcano could be impossible and the risks to human life great.

Facilities located farther away from the volcano may have additional time to prepare for the adverse effects of an eruption; however, an emergency plan should be developed and ready prior to the onset of an eruption. The planning for volcanic emergencies is similar to that for other emergencies, such as flooding or extreme weather. The sources of emergency information are often the same and the usual interruption of essential services may result. Thus, planning for interruptions in electrical service, transportation (especially vehicular travel), and outdoor activities is appropriate for volcanic emergencies.

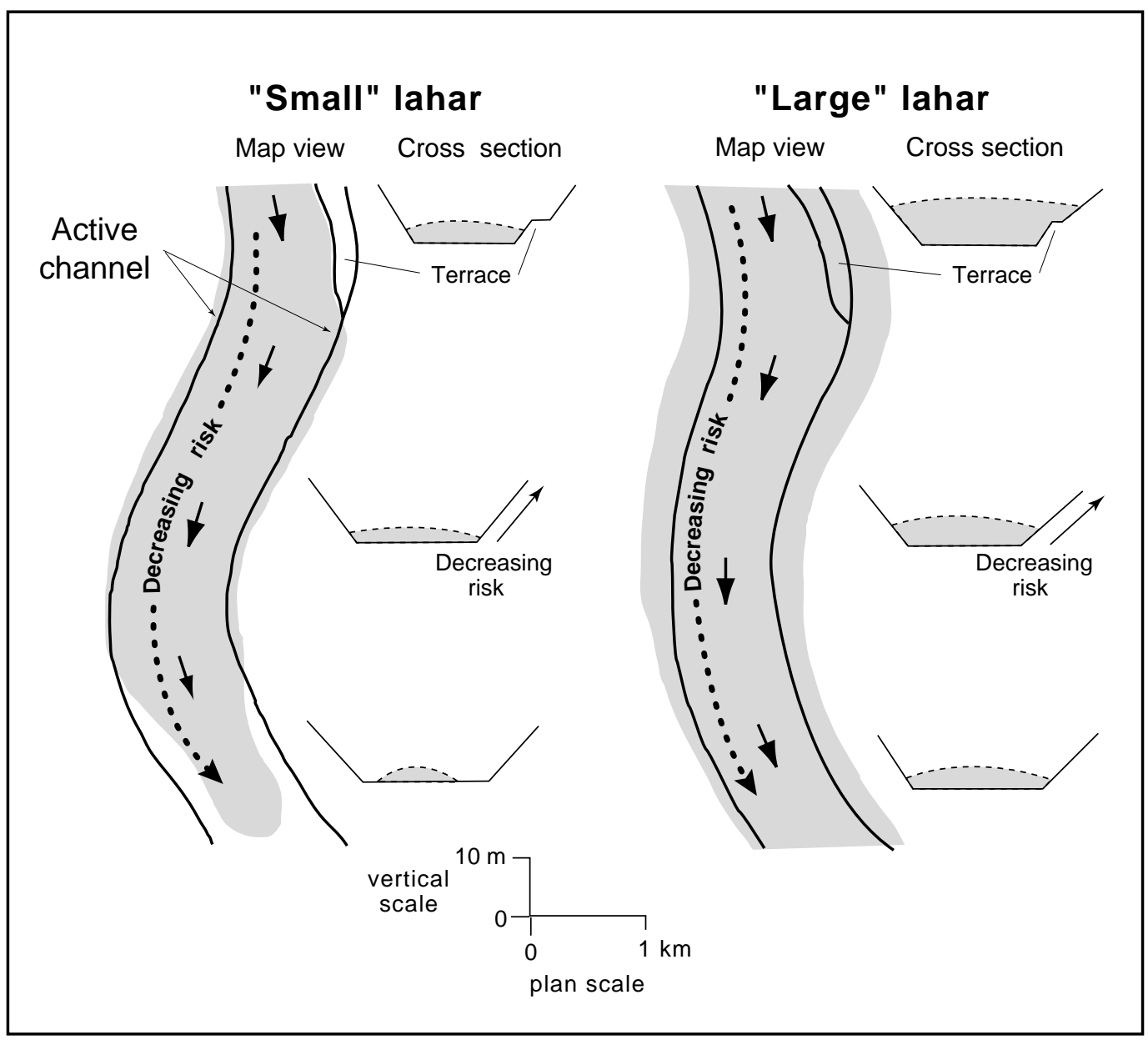

Figure 25. Relative amount of risk from "small" versus "large" lahars moving down a typical stream channel. In many situations, the hazard may be avoided simply by moving to higher ground (modified from Crandell, 1980). 


\section{REFERENCES CITED}

Alaska Volcano Observatory Staff, 1990, The 1989-90 eruption of Redoubt Volcano: Eos, Transactions of the American Geophysical Union, v. 71, p. 265, 272, 273, and 275.

Beaglehole, J.S., 1967, The journals of Captain James Cook on his voyages of discovery, III: The voyage of the Resolution and Discovery, 1776-1780: Cambridge, Cambridge University Press, p. 370.

Begét, J., Mason, O., and Anderson, P., 1992, Age, extent, and climatic significance of the ca. 3400 BP Aniakchak tephra, western Alaska, USA: The Holocene, v. 2, no. 1, p. 51-56.

Begét, J.E., and Nye, C.J., 1994, Postglacial eruption history of Redoubt Volcano, Alaska, in Miller, T.P. and Chouet, B.A., eds., The 1989-1990 eruptions of Redoubt Volcano, Alaska: Journal of Volcanology and Geothermal Research, v. 62, p. 31-54.

Blong, R.J., 1984, Volcanic hazards, a sourcebook on the effects of eruptions: Sydney, Academic Press, $424 \mathrm{p}$.

Brantley, S.R., ed., 1990, The eruption of Redoubt Volcano, Alaska, December 14, 1989-August 31, 1990: U.S. Geological Survey Circular 1061, 33 p.

Cas, R.A.F., and Wright, J.V., 1987, Volcanic successions-Modern and ancient: A geological approach to processes, products, and successions: London, Allen and Unwin, $528 \mathrm{p}$.

Casadevall, T.J., 1994a, The 1989-1990 eruption of Redoubt Volcano, Alaska-Impacts on aircraft operations, in Miller, T.P. and Chouet, B.A., eds., The 1989-1990 eruptions of Redoubt Volcano, Alaska: Journal of Volcanology and Geothermal Research, v. 62, p. 301-316.

Casadevall, T.J., (ed), 1994b, Volcanic ash and aviation safety: Proceedings of the First International Symposium on Volcanic Ash and Aviation Safety: U.S. Geological Survey Bulletin 2047, 450 p.

Casadevall, T.J., Doukas, M.P., Neal, C.A., McGimsey, R.G., and Gardner, C.A., 1994, Emission rates of sulfur dioxide and carbon dioxide from Redoubt Volcano, Alaska during the 1989-1990 eruptions, in Miller, T.P. and Chouet, B.A., eds., The 1989-1990 eruptions of Redoubt Volcano, Alaska: Journal of Volcanology and Geothermal Research, v. 62, p. 519-520.
Crandell, D.R., 1980, Recent eruptive history of Mount Hood, Oregon and potential hazards from future eruptions: U.S. Geological Survey Bulletin 1492, $81 \mathrm{p}$.

Dall, W.H., 1870, Alaska and its resources: Boston, Lee and Shepard, $627 \mathrm{p}$.

Dorava, J.M., and Meyer, D.F., 1994, Hydrologic hazards in the lower Drift River basin associated with the 1989-1990 eruptions of Redoubt Volcano, Alaska, in Miller, T.P. and Chouet, B.A., eds., The 1989-1990 eruptions of Redoubt Volcano, Alaska: Journal of Volcanology and Geothermal Research, v. 62 , p. $387-407$.

Eichelberger, J.C., Keith, T.E.C., Miller, T.P., and Nye, C.J., 1995, The 1992 eruptions of Crater Peak Vent, Mount Spurr Volcano, Alaska: Chronology and summary, in Keith, T.E.C., ed., The 1992 eruptions of Crater Peak Vent, Mount Spurr Volcano, Alaska: U.S. Geological Survey Bulletin 2139, p. 1-18.

Fread, D.L., Lewis, J.M., and Wiele, S.M., 1991, The National Weather Service simplified dam-break flood forecasting model: Federal Emergency Management Agency, $10 \mathrm{p}$.

Gardner, C.A., Neal, C.A., Waitt, R.B., and Janda, R.J., 1994, Proximal pyroclastic deposits from the 19891990 eruption of Redoubt Volcano, AlaskaStratigraphy, distribution, and physical characteristics, in Miller, T.P. and Chouet, B.A., eds., The 1989-1990 eruptions of Redoubt Volcano, Alaska: Journal of Volcanology and Geothermal Research, v. 62 , p. $213-250$.

Hayashi, J.N., and Self, S., 1992, A comparison of pyroclastic flow and debris avalanche mobility: Journal of Geophysical Research, v. 97, p. 9063-9071.

Hoblitt, R.P., Miller, C.D., and Vallance, J., 1981, Origin and stratigraphy of the deposit produced by the May 18 directed blast, in Lipman, P.W., and Mullineaux, D.R., eds., The 1980 eruptions of Mt. St. Helens, Washington: U.S. Geological Survey Professional Paper 1250, p. 401-419.

Keith, T.E.C., ed., 1995, The 1992 eruptions of Crater Peak Vent, Mount Spurr Volcano, Alaska: U.S. Geological Survey Bulletin 2139, 220 p.

Latter, J.H., 1981, Tsunamis of volcanic origin-Summary of causes, with particular reference to Krakatoa, 1883: Bulletin of Volcanology, v. 44, p. 467490. 
Miller, T.P., 1994, Dome growth and destruction during the 1989-1990 eruption of Redoubt Volcano, in Miller, T.P. and Chouet, B.A., eds., The 1989-1990 eruptions of Redoubt Volcano, Alaska: Journal of Volcanology and Geothermal Research, v. 62, p. 197-212.

Miller, T.P., and Chouet, B.A., 1994, The 1989-1990 eruptions of Redoubt Volcano: An introduction, in Miller, T.P. and Chouet, B.A., eds., The 1989-1990 eruptions of Redoubt Volcano, Alaska: Journal of Volcanology and Geothermal Research, v. 62, p. 110.

Moore, J.G., and Sisson, T.W., 1981, Deposits and effects of the May 18 pyroclastic surge, in Lipman, P.W., and Mullineaux, D.R., eds., The 1980 eruptions of Mt. St. Helens, Washington: U.S. Geological Survey Professional Paper 1250, p. 421-438.

Petroff, I., 1884, Report on the population, industries, and resources of Alaska: U.S. Census Office, Census Report, 10th Census, v. 8, 189 p.

Riehle, J.R., 1985, A reconnaissance of the major Holocene tephra deposits in the upper Cook Inlet region, Alaska: Journal of Volcanology and Geothermal Research, v. 26, p. 37-74.

Riehle, J.R., Kienle, J., and Emmel, K.S., 1981, Lahars in Crescent River valley, lower Cook Inlet, Alaska: Alaska Department of Natural Resources, Alaska Geological and Geophysical Surveys, Geologic Report 53, $10 \mathrm{p}$.

Scott, W.E., and McGimsey, R.G., 1994, Character, mass, distribution, and origin of tephra-fall deposits of the 1989-1990 eruption of Redoubt Volcano, south-central Alaska, in Miller, T.P. and Chouet, B.A., eds., The 1989-1990 eruptions of Redoubt Volcano, Alaska: Journal of Volcanology and Geothermal Research, v. 62, p. 251-272.

Simkin, T., and Siebert, L., 1994, Volcanoes of the world: Tucson, Geoscience Press, 349 p.

Steenblik, J.W., 1990, Volcanic ash-A rain of terra: Airline Pilot, June/July, p. 9-15.

Sturm, M., Benson, C., and MacKeith, P., 1986, Effects of the 1966-68 eruptions of Mt. Redoubt on the flow of Drift Glacier, Alaska, U.S.A.: Journal of Glaciology, v. 32, p. 355-362.

Sturm, M., Benson, C., and MacKeith, P., 1988, Recent glacier-volcano interactions on Mt. Redoubt, Alaska: Alaska Division of Geological and Geophysical Surveys Report of Investigations 88-9, 18 p.
Till, A.B., Yount, M.E., and Bevier, M.L., 1994, The geologic history of Redoubt Volcano, Alaska, in Miller, T.P. and Chouet, B.A., eds., The 1989-1990 eruptions of Redoubt Volcano, Alaska: Journal of Volcanology and Geothermal Research, v. 62, p. 11-30.

Till, A.B., Yount, M.E., and Riehle, J.R., 1993, Redoubt Volcano, southern Alaska-A hazard assessment based on eruptive activity through 1968: U.S. Geological Survey Bulletin 1996, 19 p.

Trabant, D.C., and Meyer, D.F., 1992, Flood generation and destruction of "Drift" Glacier by the 1989-90 eruption of Redoubt Volcano, Alaska: Annals of Glaciology, v. 16, p. 33-38.

Tuck, B.H., and Huskey, L., 1992, The economic consequences of the 1989-90 Mt. Redoubt eruptions: University of Alaska, Anchorage, Institute of Social and Economic Research, 36 p.

Tuck, B.H., and Huskey, L., 1994, Economic disruptions by Redoubt Volcano: Assessment methodology and anecdotal empirical evidence, in Casadevall, T.J., ed., Volcanic ash and aviation safety: Proceedings of the First International Symposium on Volcanic Ash and Aviation Safety: U.S. Geological Survey Bulletin 2047, p. 137-140.

van Bemmelen, R.W., 1949, Report on the volcanic activity and volcanological research in Indonesia during the period 1936-1948: Bulletin Volcanologique, v. 9, p. 3-30.

Voight, B., Glicken, H., Janda, R.J., and Douglass, P.M., 1981, Catastrophic rockslide avalanche of May 18, in Lipman, P.W., and Mullineaux, D.R., eds., The 1980 eruptions of Mt. St. Helens, Washington: U.S. Geological Survey Professional Paper 1250, p. 347377 .

\section{GLOSSARY}

Ash. Fine fragments (less than 2 millimeters across) of lava or rock formed in an explosive volcanic eruption.

Debris avalanche. Rapidly moving, dry flows of dissaggregated rock debris, sand, and silt. Volcanic debris avalanches often form by some type of structural collapse of the volcano, usually the steep front of the cooled lava dome, or other parts of the upper edifice. A large portion of the volcano may become unstable, break away from the volcanic massif, and become an avalanche. A debris avalanche may be 
triggered by an eruption or earthquake. Debris avalanches move at velocities ranging from a few tens of meters per second to more than 100 meters per second and behave like complex granular flows or slide flows. Often they are quite voluminous ( greater than 10 cubic kilometers) and may run out considerable distances (up to 85 kilometers) from their source. The resulting debris avalanche deposit usually exhibits hummocky surface morphology.

Directed blast. Large-scale volcanic explosion caused by a major landslide or slope failure that results in a rapid drop in the pressure of the intruding magma near the surface of the volcanic edifice. The 1980 eruption of Mt. St. Helens was triggered by a massive slope failure and the subsequent laterally directed blast affected a $180^{\circ}$ sector north of the volcano and extended for several tens of kilometers outward (Hoblitt and others, 1981). A directed blast typically travels away from the volcano at a low angle and may not be deflected by ridges or other topographic barriers. Rock debris propelled by a directed blast moves much faster than typical landslides and rockfalls. For example, at Mt. St. Helens, the initial velocity of the directed blast cloud was about 600 kilometers per hour decreasing to about 100 kilometers per hour at a distance 25 kilometers from the volcano (Moore and Sisson, 1981).

Eruption cloud. Cloud of gas, ash, and other fragments that forms during an explosive volcanic eruption and travels long distances with the prevailing winds.

Eruption column. The vertical portion of the eruption cloud that rises above a volcanic vent

Ejecta. General term for anything thrown into the air from a volcano during an eruption; synonymous with pyroclast which means "fire" and "broken piece."

Fallout. A general term for debris which falls to the earth from an eruption cloud.

Lahar. An Indonesian term for a debris flow containing angular clasts of volcanic material (van Bemmelen, 1949). For the purposes of this report, a lahar is any type of sediment/water mixture originating on or from the volcano. Most lahars move rapidly down the slopes of a volcano as channelized flows and deliver large amounts of sediment to the rivers and streams that drain the volcano. The flow velocity of some lahars may be as high as 20 to 40 meters per second (Blong, 1984) and sediment concentrations of $>750,000$ parts per million are not uncommon.
Large volume lahars can travel great distances if they have an appreciable clay content (> 3 to 5 percent), remain confined to a stream channel, and do not significantly gain sediment while losing water. Thus, they may affect areas many tens to hundreds of kilometers downstream from a volcano.

Lapilli. Ejected rock or pumice fragments between 2 and 64 millimeters in diameter.

Lava. Molten rock that reaches the earth's surface.

Lava dome. A steep sided mass of viscous and often blocky lava extruded from a vent; typically has a rounded top and roughly circular outline.

Lithic. Synonym for "rock" in volcanic deposits, refers to fragments of pre-existing rock as opposed to newly erupted material.

Magma. Molten rock beneath the earth's surface.

Pumice. Highly vesicular volcanic ejecta; due to its extremely low density, it often floats on water.

Pyroclastic. General term applied to volcanic products or processes that involve explosive ejection and fragmentation of erupting material.

Pyroclastic flow. A dense, hot, chaotic avalanche of rock fragments, gas, and ash that travels rapidly away from an explosive eruption column, often down the flanks of the volcano (synonymous with "ash flow"). Pyroclastic flows move at speeds ranging from 10 to several hundred meters per second and are typically at temperatures between 300 and $800{ }^{\circ} \mathrm{C}$ (Blong, 1984). Pyroclastic flows form either by collapse of the eruption column, or by failure of the front of a cooling lava dome. Once these flows are initiated, they may travel distances of several kilometers or more and easily override topographic obstacles in the flow path. A person could not outrun an advancing pyroclastic flow.

Pyroclastic surge. A low-density, turbulent flow of fine-grained volcanic rock debris and hot gas. Pyroclastic surges differ from pyroclastic flows in that they are less dense and tend to travel as a low, ground-hugging, but highly mobile cloud that can surmount topographic barriers. Surges often affect areas beyond the limits of pyroclastic flows.

Stratovolcano. (Also called a stratocone or composite cone.) A steep-sided volcano, usually conical in shape, built of lava flows and fragmental deposits from explosive eruptions.

Tephra. Tephra is any type of rock fragment that is forcibly ejected from the volcano during an eruption. Tephra may be fine-grained dust or "ash" 
(0.0625 to $2 \mathrm{~mm}$ diameter -- silt to sand sized), coarser "lapilli" (2 to $64 \mathrm{~mm}$ diameter -- sand to pebble sized), or consist of large blocks or bombs (>64 mm -- cobble to boulder sized). When tephra is airborne, the coarsest fraction will be deposited close to the volcano, but the fine fraction may be transported long distances and can stay suspended in the atmosphere for many months. Tephra particles are typically sharp, angular, and abrasive, and are composed of volcanic glass, mineral, and rock fragments.

Tsunami. Widely spaced, fast-moving ocean waves most commonly initiated by sudden displacements of the sea floor during earthquakes. Volcanic eruptions can also cause tsunamis if unconsolidated volcanic sediment flows rapidly or falls into the water as in a catastrophic slope failure from a steep-sided volcanic cone or edifice, or if explosive eruptions occur at or near sea level. Tsunamis are capable of inundating significant portions of the coastline, especially if the wave energy is focused by narrowing of inlets and bays.

Vent. An opening in the earth's surface through which magma erupts or volcanic gasses are emitted.

Volcaniclastic. A general term for either unconsolidated deposits or rocks composed of particles that are volcanic in origin. 